Int. J. Adv. Eng. Pure Sci. 2019, I: I-16

DOI: 10.7240/jeps.444190

REVIEW / DERLEME

\title{
Sağlıkta Güncel Simülasyon Yaklaşımları: Bir Derleme Çalışması
}

\author{
Recent Simulation Studies in Healthcare: A Review
}

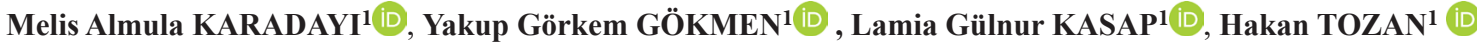 \\ ${ }^{1}$ Ístanbul Medipol Üniversitesi, Endüstri Mühendisliği Bölümü, 34810, İstanbul, Türkiye
}

Öz

Son on yılda, sağlık hizmeti maliyetlerindeki çarpıcı artış, araştırmacıları ve sağlık politikacılarını maliyetleri düşürmek için yeni yollar bulmaya zorlamıştır. Simülasyon, sağlık hizmetlerinde verimliliği artırmak ve kaliteyi yükseltmek için kullanılan popüler ve etkili bir yöntem haline gelmiştir. Araştırmacıların sağlık hizmetlerinde gerçekleştirilen simülasyon çalışmalarına olan ilgileri, yayın sayısında sürekli bir artışa neden olmuştur. Bu derleme çalışmasında, sağlık alanında gerçekleştirilen ayrık olay simülasyonu (AOS) çalışmaları özetlenmiş ve sınıflandırılmıştır. Özellikle de yüksek düzeyde belirsizlik ve kısıtlı kaynaklar altında çalışan ameliyathanelerde gerçekleştirilen AOS çalışmalarına odaklanılmıştır. Ayrıca derleme çalışmasının sonucunda simülasyon tabanlı optimizasyon yöntemi ile ameliyathane çizelgeleme süreçlerinin iyileştirilmesi konusunda literatürde var olan eksiklikler belirlenmiştir. Bu doğrultuda, sağlık alanında çalışan araştırmacılar ve profesyoneller gelecek AOS araştırma ve uygulamaları hakkında yeni çalışmalarda bulunabilirler.

Anahtar Kelimeler: Ayrık Olay Simülasyonu, Hastane, Sağlık, Simülasyon

\begin{abstract}
In recent decades, the dramatic increase in healthcare costs has compelled resarchers and healthcare policy makers to find out new ways to reduce costs. Simulation has become a popular and effective method for improving efficiency and enhancing quality in healthcare operations. The interest of researchers in the domain of simulation studies in healthcare induces a steady increase in the number of publications. In this regard, different discrete-event simulation (DES) studies employed in healthcare field are summarized and classified in this review. A particular attention is on the published studies that involve DES studies of operating rooms. The operating room is specifically the most complicated and expensive hospital resource that runs with high level of uncertainty and limited resources. Moreover, as a result of this review study, deficiencies in the literature about the improvement of the operating room scheduling processes with simulation based optimization method have been determined. In the literature, most of the simulation models only include demand and capacity constraints. However, they should include more constraints such as labor constraints, preferences of surgeons for surgical scheduling, number of available beds in intensive care unit, number of recovery beds, etc. Moreover, there is a need in the field to develop stochastic models, which involve uncertain surgery and recovery times. In most of the studies, it is assumed that these periods are known precisely. It is also determined that number of multi-objective models is quite low. In addition, only a few simulation studies have an online scheduling approach. Thus, these issues need to be addressed. In light of this review, healthcare professionals and researchers can make new suggestions and improvements regarding future research and applications of DES.
\end{abstract}

Keywords: Discrete-Evet Simulation, Hospital, Healthcare, Simulation

\section{GİRIŞ}

Gelişen teknoloji ve hizmet sektöründe yaşanan yüksek rekabetle birlikte sağlık sistemleri üzerine yapılan çalışmalara son yıllarda giderek artan ölçüde ivme kazandırılmıştır. Sağlık kurumlarında yapılan süreç iyileştirmeleri sayesinde kurumların maliyetlerinde düşüş sağlanırken hasta memnuniyeti ve hizmet kalitesi artırılabilmektedir. Bu doğrultuda, literatürde sağlık süreçlerinin iyileştirilmesi konusuna odaklanan birçok uluslararası çalışma mevcuttur. Ülkemizde ise bu sayının az olması konunun önemini biraz daha artırmakta ve gelecek çalışmalara yol gösterici olmak hedefiyle beraber bu çalışmanın temel motivasyonlarından birini oluşturmaktadır. 
Gerçekleştirilen simülasyon çalışmalarında hastane birimleri ayrı ayrı ele alınabilmektedir. Bu birimlerden "Ameliyathaneler" ise hastane işletmelerinin en pahalı ve karmaşı süreçlerini içerdikleri için kritik öneme sahip birimler olarak karşımıza çıkmaktadır. Ameliyathane süreçlerinin planlanmasını etkileyen birçok faktör vardır. Bir ameliyatı gerçekleştirmek için gereken kaynaklar; ameliyat personeli (cerrahlar, anestezistler, hemşireler, vb.), özel ekipmanlar, ameliyat odaları, anestezi sonrası bakım üniteleri ve yoğun bakım üniteleri olarak ele alınabilir. Ameliyathane süreçlerinin planlanmasını etkileyen bir diğer faktör de bazı ameliyatlar planlanabilirken bazılarının acil durumlar sonucu oluşması ve ani müdahale gerektiren ameliyatlar olmasıdır. Üstelik bu süreç hasta alım süreci, iyileşme süreci, ameliyatlar, acil hasta gelişi ve tıbbi personelin müsait olması gibi birçok belirsizlikleri de barındırmaktadır. Bu belirsizlikler; ameliyathane ekibini bekleme zaman1, ameliyathane odas1nın boş kalması, fazla mesai, ameliyathanenin kullanım verimliliği ve bakım kalitesi gibi birçok problemi doğurmaktadır. Tüm bu faktörleri ve belirsizlikleri aynı zamanda ele almak problemin yapısını oldukça karmaşık bir hale getirmektedir. Bu nedenle tüm bu yapıyı ele alan modelleri çözmek zor ya da imkansız olabilmektedir. İlgili literatürde modelin zorluğundan dolayı bu konu farklı bölümlere ayrılmış ve genel olarak sadece planlanabilen ameliyatlar ya da acil ameliyatların çizelgelenmeleri üzerine çalışılmıştır. Tüm sistemi ele alan çalışmalarda ise problemin karmaşıklığından dolayı çözüm yöntemi olarak sezgisel yöntemlere ya da simülasyon tekniklerine başvurulmuştur.

$\mathrm{Bu}$ amaçla, derleme çalışması kapsamında genel olarak sağlık sektöründe gerçekleştirilen simülasyon çalışmaları ayrıntılı bir şekilde özetlenmiştir. Kurgulanan sınıflandırma şemasına Bölüm 2 içerisinde yer verilmiştir. Kritik öneme sahip ameliyathanelere odaklanan; Ameliyathane çizelgeleme süreçlerinde gerçekleştirilen simülasyon çalışmalarına ise Bölüm 3'te yer verilmiştir. Yine bu bölüm içerisinde önerilen sınıflandırma şemasına ve çalışmalarda gözlemlenen ana hedeflerin listesine yer verilmiştir. Sonuç bölümde ise gerçekleştirilen derleme çalışmasının analizi yapılmış, literatürdeki konuyla ilgili eksiklikler belirtilmiş ve elde edilen bulgular hakkında bilgi verilmiştir.

\section{SAĞLIK SEKTÖRÜNDE SIMÜ̈LASYON ÇALIŞMALARI}

Bu bölüm, sağlı sektöründe gerçekleştirilen simülasyonla modelleme çalışmalarının kapsamlı bir özetini içermektedir. “Simülasyon modellerinin' sağlık hizmeti sunumunda sağllk hizmeti veren yöneticiler ve profesyoneller tarafindan etkili bir araç olarak kullanıldığı çok sayıda örnek bulunmaktadır.
Bunun en önemli nedeni simülasyon modellerinin belirsizliklerle başa çıkmak için uygun olmalarının yanı sıra darboğazları azaltmak, operasyonel verimliliği artırmak, maliyeti azaltmak ve bakım kalitesini artırmak gibi sistemdeki problemleri çözmek için kolaylıkla kullanılabilmeleridir. Literatürde bu alanda yer alan çalışmalar şu şekilde özetlenebilir: Özelllikle tıp öğrencileri için simülasyon temelli eğitim çalışmaları [Schroedl ve diğ. (2012); Jansson ve diğ. (2013); Ballangrud ve diğ. (2014); Wenk \& Pöpping (2015); Warren ve diğ. (2016); Mirza \& Athreya (2017); Camp \& Legge (2018)], hasta güvenliği ve servis kalitesi konusunda yapılan çalışmalar [Reed ve diğ., (2017)], hastalıkların taranması konusunda gerçekleştirilen çalışmalar [Fabian et al. (2012); Chemweno ve diğ. (2014); Ariöz \& Günel, 2016; Pan ve diğ. (2017)], enfeksiyon ve bulaşıcı hastalıklar konusunda yapılan çalışmalar [Nikakhtar \& Hsiang; Viana ve diğ. (2014); Orbann ve diğ. (2017)], kaynak planlaması ve yönetimi konusuna odaklanan çalışmalar [Sadatsafavi ve diğ. (2016)] ve en çok ilgi gören araştırma alanı ise son kategori olan "çizelgeleme ve hasta akışı"na aittir. [Granja ve diğ. (2014); Ben-Tovim ve diğ. (2016); Ahmadi-Javid ve diğ. (2017)].

Sağlık alanında gerçekleştirilen simülasyon ve modelleme ile ilgili daha önce yapılan literatür taraması çalışmaları sırasıyla; Jun ve diğ. (1999), Fone ve diğ. (2003) ve Günal \& Pidd (2010)'a aittir. June ve diğ. (1999) hasta akış1 (örneğin: hasta planlaması ve kabulleri, hastanın yönlendirilmesi ve akışşemaları, kaynakların planlanması ve kullanılabilirliği) ve kaynak tahsisi alanında (örneğin: yatak kullanımının planlanması, hasta odası kullanımının planlanması, personel atamalarının planlanması) Ayrık Olay Simülasyonu (AOS) yaklaşımı üzerine literatür taraması yapmışlardır. Fone ve diğ. (2003) 1980-1999 yılları arasında hastane planlaması ve organizasyonu, enfeksiyon ve bulaşı1 hastalıklar, maliyet ve ekonomik değerlendirme ve tarama ile ilgili sağlık hizmetlerinde gerçekleştirilen simülasyon modellerini gözden geçirmişlerdir. Yenilikçi bir çalışma olarak, Günal \& Pidd (2010), kaza ve acil servis hizmetleri, yatarak tedavi bölümü, ayakta tedavi bölümü gibi ünitelere özgü hastane birimlerine simülasyon modellerinin uygulanmasını araştırmışlardır. Özellikle simülasyon modellerinin özgünlükten eksik olduklarını raporlayıp, sağlık hizmetlerinde performans modellemesi için kapsamlı yaklaşımların gerekliliğine işaret etmişlerdir. Bu çalışmaların hepsi zaman ve maliyet boyutlarının dahil edildiği daha kompleks simülasyon modellerinin eksikliğini vurgulamaktadırlar.

AOS hastane yöneticilerine "eğer?" sorusunu sorarak mevcut sağlık hizmeti sistemlerinin performansını değerlendirme ve yeni sistemler geliştirme olanağ 1 sunar. AOS'nin bireysel doğası hastane ortamı gibi küçük nüfuslu yerleri modellemeyi uygun hale getirmektedir. AOS ayrıca, hasta 
akışındaki değişimlerin etkisini tahmin etmek, işgücü ve kaynak kapasitelerini araştırmak veya hasta geliş oranı ile mevcut hizmet oranı arasındaki karmaşık ilişkileri incelemek için de kullanılabilir. Bu bilgiler sağlık yöneticilerine verimliliği artırmak için mevcut sistemleri yeniden yapılandırmalarını ya da yeni sistemleri planlamalarını sağlar. (Jun ve diğ., 1999). Ayrıca, sistem dinamiği gibi (Faezipour \& Ferreira (2013); Kumar \& Kumar (2014); Gonul Kochan ve diğ. (2018)) ya da ajan tabanlı modelleme gibi (Cabrera ve diğ. (2011); Silverman ve diğ. (2015); Liu ve diğ. (2017)) AOS yaklaşımları dışındaki alanda da simülasyon modelleme örnekleri de vardır. Bu yöntemlere ek olarak, sezgisel optimizasyon [Aringhieri ve diğ.; Molina-Pariente ve diğ.; Xiang ve diğ. (2015)] gibi simülasyon kullanılmayan teknikler de mevcuttur.

$\mathrm{Bu}$ derleme çalışması kapsamında, "Sağlık hizmetlerinde son on y1lda gerçekleştirilen simülasyon çalışmalarını" analiz etmek adına, bu süre zarfında yayınlanan çalışmaların sistematik olarak incelemesi yapılmışırı. Çalışmanın odak noktası ise sağlık hizmetlerinde sistem verimliliğini artırmak için kullanılan AOS modelleri olmuştur. Daha önceki çalışmaların analizi, araştırmacıların belirli bir hastane ünitesine odaklandıklarını ve bir simülasyon modelinde karmaşıklık, veri ihtiyaçları, zaman ve para gereksinimleri ile başa çıkabilmek için hastane süreçlerinin bir kısmını etkisiz hale getirdiklerini ortaya koymaktadır. Mevcut literatürden yararlanarak, simülasyon çalışmaları hastanenin uygulama ünitesine bağlı olarak beş grupta incelenmiştir. Böylece, hastanenin bölümleri (1) acil servis bölümü (ASb), (2) ayakta tedavi bölümü, (3) yatarak tedavi bölümü, (4) yoğun bakım üniteleri ve eczaneler, (5) ameliyathane olmak üzere beş gruba ayrılmıştır. Önerilen sınıflandırma şemasına Şekil 1'de gösterilmektedir. Hastanelerin farklı birimlerinde gerçekleştirmiş olan AOS çalışmalarının kapsam ve içeriğine gelecek bölümlerde ayrıntılı olarak yer verilmiştir.

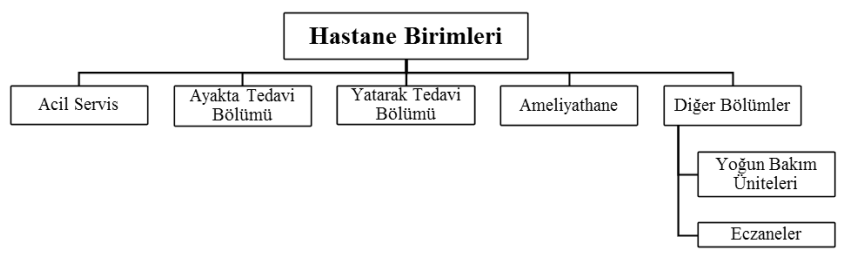

Şekil 1. Simülasyon çalışmalarının sınıflandırılması

\subsection{Acil Servis}

Birinci çalışma grubu, acil servis birimlerinde (ASb) uygulanan AOS çalışmalarını içermektedir. Simülasyon çalışmaları, hastanın ortalama bekleme süresini kısaltarak, sağlık personelini ve hizmet verilen hasta sayısını artırarak ASb'nin mevcut performansını iyileştirmek için kullanılmıştır.

Hoot ve di ğ. (2008) ASb'nin gelecekteki çalışma koşullarının tahmin edilmesi ile ilgili bir çalışma sunmuşlardır. 400 gün boyunca 57.995 hastayı kaydederek ve bu verileri, ASb kalabalıklaşma problemini çözebilecek ve önleyecek bir sistem tasarlamak için talep tahmini simülasyonunda kullanmışlardır. Çalışmada, öngörülen ve fiili çalışma koşulları (hasta bekleme süresi, doluluk seviyesi, hasta kalış süresi, yatan hasta sayısı, yatış süresi ve ambulans güzergâhı değiştirme gibi) arasındaki ilişkiyi incelenmişlerdir. Khurma ve diğ. (2008), ASb işlemlerinin verimliliğini artırmak için ProModel yazılım simülasyonu gibi Yalın Üretim araçlarını kullanmışlardır.

Zeng ve diğ. (2012), Lexington, Kentucky'de hizmet veren ASb'nin potansiyel kullanımının verimliliğini artırmak için SIMUL8 yazılımını kullanarak bir simülasyon modeli tasarlamışlardır. ASb'de kalma süresi, bekleme süreleri, ekipman kullanımı, hasta girdi-çıktı bilgileri ve personel verileri hastaneden toplanmış ve incelenmiştir. Yapılan analizler sonrasında hemşirelerin, doktorların ve Bilgisayarlı Tomografi (BT) cihazlarının sayısının, kalış süresi, bekleme süresi ve hasta seçiminde önemli bir etkisinin olduğunu göstermişlerdir. Ortalama bekleme süresini \%13, kalış süresini $\% 5$ ve hasta kayıplarını $\% 25$ oranında azaltmayı başarmışlardir.

Al-Refaie ve diğ. (2014), Ürdün'deki bir hastanede ASb için kapasite, maliyet ve mevcut kaynak kısıtlamalarını karşılayan 10 olası çalışma senaryosu arasından en iyi senaryoyu seçmek için simülasyon ve Veri Zarflama Analizi (VZA) yöntemlerini birleştirmişlerdir.

Best ve diğ. (2014), Gana'da bir belediye hastanesinde hizmet verilen hasta sayısının artırılması amaciyla acil bakım süreci için bir AOS modeli oluşturmuşlardır. Simülasyon modeli, Arena Simülasyon Yazılımı tarafından oluşturulup; karar vericiler, personel gibi ek kaynakların etkilerini ve modifiye personel başlangıç zamanları ve mevcut sistem üzerindeki rolleri gibi kapasite tahsisinde meydana gelen değişiklikleri analiz etmişlerdir. Yapılan analizler sonucunda, bu değişikliklerin, acil sağlık sistemi için kalma süresini azaltarak hasta akışını geliştirdiğini göstermişlerdir.

Radhakrishnan ve diğ. (2014) birincil bakımda hastalar için giyilebilir sağlık izleme cihazları üzerinde çalışmışlardır. Bu cihazlarla, pratisyen hekimler hastanın kalp atışlarını, kan basıncını, solunumlarını internet üzerinden kontrol edebilmişlerdir. Böylece, hasta sırasını azaltmak, zamandan tasarruf etmek, operasyon maliyetlerini azaltmak ve çeşitli sağlık birimleri arasındaki iletişimi artırmak için giyilebilir 
sağlık izleme sistemini önermişlerdir. Mevcut hasta akışını modellemek için AOS kullanılmıştır.

Lin ve diğ. (2015), Ambulans Yönlendirme (AY) stratejilerini değerlendirebilen bir model sunmuşlardır. AY aralıklarını, AY başlangıç ölçütlerini analiz etmek için üç farklı simülasyon modeli önermişlerdir.

Azadeh ve diğ. (2016), İran'daki bir hastanenin ASb hizmet kalitesini iyileştirmek için tekrarlanan damar tıkanıklığı, güvensiz ulaşım ve örnekleme gibi insana dayalı (hemşireler ve teknisyenler gibi) faktörleri analiz etmişlerdir. Bekleyen hasta sayısını azaltmak ve hataları tespit etmek için toplam 70 senaryo tanımlamışlardır. Bu yöntemleri değerlendirmek için rassal veri zarflama analizi yöntemini kullanmışlardır. Senaryoları simüle etmek için AOS modellerinden biri olan AweSim kullanmışlardır. Elde edilen sonuçlara dayanarak, başarılı sonuçlar veren senaryo modeller uygulandığında ASb'nin toplam performansının iyileștirilebileceği kanıtlanmıştır.

Ünlüyurt \& Tunçer (2016) ambulansların kullanım verimliliğine odaklanmışlardır. En yakın ambulansın yoğun olduğu durumda müsait olan başka bir ambulansın yönlendirilebileceği deterministik ambulans yeri modelinin çözümü için simülasyon tekniğini kullanmışlardır. Önerilen modelin test edilmesi için çalışmada, Türkiye'nin en büyük şehri olan İstanbul'a ait verileri kullanmışlardır.

\subsection{Ayakta Tedavi Bölümü}

İkinci çalışma grubu, ayakta tedavi bölümünde uygulanan AOS çalışmalarını içermektedir. Ayakta tedavi bölümleri ve ASb'ler benzer özelliklere sahip oldukları için AOS yöntemi bu birimler için de sıklıkla kullanılmaktadır. Ayakta tedavi hizmeti veren birimlerin ASb'nden en önemli farkları ise ayakta tedavi bölümlerinde ana hedefin kapasite planlaması olmasıdır. (Günal \& Pidd, 2010).

Coelli ve diğ. (2007) bir mamografi taramasının analizi için AOS modeli önermişlerdir. Önerilen çalışmada, kaynaklar ve süreçlerin tanımlanmasına dayanan Medmode 6.0 yazılımını kullanarak, beklenen hasta akış hızını göz önünde bulundurarak verimliliğin artırılmasına yönelik stratejinin belirlenmesine odaklanmışlardır. Kapamara (2007) İngiltere'deki Arden Kanser Merkezi'nde radyoterapi sürecinin Simul8 olarak adlandırılan AOS tabanlı bir yazılım kullanarak simülasyon modellemesini yapmıştır. Kapamara (2007) çalışmasında, hastalar ve ekipman olanakları arasındaki ilişkideki darboğaz ve komplikasyonları belirlemeyi, bununla beraber hasta akışlarını araştırmaya odaklanmıştır.

J. Klassen (2009) daha fazla değişkeni ve çevresel faktörleri dikkate alabilen simülasyon tabanlı bir optimizasyon modeli önermiştir. En iyi sonuç veren randevu çizelgesini belirlemek adına elde edilen senaryoların karşılaştırılması yapılmıştır.

Villamizar ve diğ. (2011) Brezilya'da hizmet veren bir fizyoterapi kliniğinin performansını incelemek için AOS yöntemini kullanmışlardır. İlk olarak, yeni sistemi simülasyon tekniği ile analiz etmişlerdir. Takip eden aşamada, 5 farklı senaryo vasitasıyla hasta sayısını, personel sayısını ve hastaların varış zamanlarını analiz etmişlerdir. Rohleder ve diğ. (2011) Kanada'da hizmet veren bir ortopedi kliniğinde hasta bekleme sürelerini iyileştirmeyi amaçlamışlardır. Çalışma sonucunda ilgili klinikte hasta bekleme sürelerini k1saltmayı başarmışlardır.

Masselink ve diğ. (2012), Hollanda Kanser Enstitüsü'nün kemoterapi ünitesinde hasta bekleme süresi ve eczane politikaları arasındaki ilişkiyi incelemişlerdir. Çalışma sonucunda, bekleme süresinin yarı yarıya azaltılmasıyla eczane maliyetlerinin sadece \%1-2 oranında artığını ortaya koymuşlardır.

Baril ve diğ. (2014) Ortopedi kliniğinin performansını değerlendirmek amaciyla kaynak planlama, randevu belirleme kuralları ve hasta gelişleri arasındaki ilişkiyi inceleyen bir yöntem önererek, literatürdeki bu boşluğu doldurmuşlardır. Çalışma sonucunda, ortalama hasta bekleme sürelerini azaltmayı başarmışlardır. Mevcut hemşire sayısı artırıldığında, ortalama hasta bekleme süresinin 30 dakikaya düştüğünü ve muayene odalarının sayısı artırıldığında hastanın ortalama bekleme süresinin 55 dakikaya düştüğünü gözlemlemişlerdir.

Peng ve diğ. (2014), MATLAB programında kodlanan AOS ve Genetik Algoritmayı (AOS-GA) kullanarak, açık erişim klinikleri ve randevusuz hastalar için en uygun çizelgeleme şablonlarını tasarlamaya çalışmışlardır. AOS ve GA tekniklerini kullanılarak, randevuların optimal yüzdesini ve optimal tahsisini bulmuşlardır. Açık erişim ve randevusuz hastaların başvuru başına ödediği ortalama maliyeti önerilen yöntemle azaltmışlardır.

Ben-Towim ve diğ. (2016), Güney Avustralya'daki bir tıp merkezinin hasta akışına odaklanmıştır. Tüm hastaneyi ayrıntılı bir şekilde temsil etmesi için Hastane Olay Simülasyon Modeli: Taburcu Edilenler'i (HOBMTE) oluşturmayı önermişlerdir. İlgili çalışma, farklı hastane müdahalelerinin "eğer" analizi için HOBMTE'nin olası uygulanabilirliğiyle alakalı bir vaka çalışmasını da kapsamaktadır. Aynı zamanda önerilen yöntem, ASb'nin olası sorunlarını belirlemek ve bazı çözüm senaryolarını oluşturmak için de kullanılabilmektedir. Baril ve diğ. (2016), sağlık hizmeti veren işletmeler arasındaki ciddi rekabet ile başa çıkmak için kendi hizmet sunum süreçlerini geliştirmeyi hedeflemişlerdir. 
Kanada'da bir Hematoloji-Onkoloji ayakta tedavi bölümündeki hastaların akışını iyileştirmek için AOS ve Yalın Yönetim kavramlarını birlikte kullanmışlardır.

Babashov ve diğ. (2017) Kanada'daki bir kanser tedavi merkezinde hasta bekleme sürelerini kısaltmak için tüm radyasyon tedavisi planlama sürecini ayrıntılı bir şekilde ele almışlardır. Hasta gelişlerini ve sistemde oluşabilecek kuyrukların görselleştirilmesini ve modellenmesine imkan veren Simul8 yazılım paketini (SIMUL8 Corporation) kullanmışlardır Ayrıca önerilen bu model ile mevcut hizmet kalitesinin artırılabileceğini de belirtmişlerdir.

\subsection{Yatarak Tedavi Bölümü}

Üçüncü çalışma grubunu, hastanelerin yatarak tedavi bölümlerinde gerçekleştirilen AOS çalışmaları oluşturmaktadır. Yatarak tedavi birimleri hastane işletmeleri için önemli olan başka bir bölümdür. Bu bölümlerde genel olarak AOS modelleri, tıbbi personel sayısına, yatak doluluk oranlarına ve hastanede kalış süresine odaklanan farklı matematiksel modelleri geliştirmek ve analiz etmek için kullanılmıştır.

Kim ve diğ. (2013), ruh sağlığı ve hastalıkları kliniğinde görev yapan personelin değişen çalışma koşullarını (terapistler, psikiyatristler) dikkate alan dört farklı senaryoyu analiz etmiş ve bu senaryoların sonuçlarını mevcut sistemle karşılaştırmışlardır.

Chemweno ve diğ. (2014), Belçika'daki bir üniversite hastanesinde inme geçiren hastaların yatış sürelerini analiz etmişlerdir. Klinikte hasta akışları ve yatak kapasitesi problemlerine odaklanmışlardır. ARENA'da toplam beş senaryo oluşturulup, sonuçlar analiz edilmiştir.

Devapriya ve diğ. (2015) hastanenin yatak kapasitesi, hasta bekleme süreleri, hastaların doluluk oranı ve maliyetleri gibi temel sorunlarına odaklanmışlardır. Bu amaçla, Stratejik Yatak Analiz Modelini mevcut sağlık sisteminin kapasitesinin nasıl artırılabileceğini araştırmak için bir AOS modeli olarak tasarlamışlardır. Önerdikleri simülasyon modellerinin genellenebilir ve diğer hastanelerin sağlık sistemleri için de uygulanılabilir olduğunu belirtmişlerdir.

\subsection{Diğer Hastane Birimleri}

Dördüncü çalışma grubunda yoğun bakım üniteleri ve eczaneler gibi diğer birimlerde gerçekleştirilen AOS çalışmaları listelenmiştir.

Reynolds ve diğ. (2011), Londra'da hastane bünyesinde hizmet veren iki eczanenin iş yükünü incelemek için ExtendSim'de bir AOS modeli tasarlamışlardır. Önerdikleri çalışmanın sonucunda, sisteme yeni bir eczacının eklenmesi, günlük iş yükünde $\% 10^{\prime} l u k$ ve aynı zamanda geri dönüş sürelerinde $\% 20$ 'lik bir düşüşe neden olmuştur. Dan ve diğ. (2016) Sichuan Üniversitesi Hastanesi'nin eczanesinde hasta bekleme sorununun çözümü için bir AOS modeli önermişlerdir. İstatistiksel sonuçlar simülasyon modelinin etkinliğini kanıtlamıştır ve simülasyon sonuçlarına göre ana problem keşfedilmiştir ve tek sıralı çok sunuculu sıralama modelinin mevcut sistemin işletim verimliliğini artırabileceğini belirtmişlerdir. Rodrigues ve diğ. (2017) hastanelerdeki karmaşık hasta akışını göstermek için bir AOS modeli tasarlamışlardır. Yoğun bakım ünitelerinde ve yatarak tedavi bölümünde kapasite ve yatak sorunlarının değişikliklerinin etkilerine yoğunlaşmışlardır. Önerdikleri model sonucunda, hasta maliyetlerini günde $\% 18$ 'e kadar düşürebilmişlerdir.

Derleme çalışması kapsamında taranan, sağlık sektöründe farklı hastane birimlerinde gerçekleştirilen simülasyon çalışmaları yayın yılı, yazar, ülke, kullanılan yöntemler, ele alınan problem ve sonuçlar bilgileri ile birlikte Tablo 1 'de özetlenmiştir.

Son kategori ise ameliyathane süreçlerinde uygulanan AOS çalışmalarına aittir. Derleme çalışmasının odak noktası bu birimler olduğundan, ameliyathane süreçlerinin simülasyon modellemesini yapan çalışmaların literatür taramasına ayrıntılı olarak Bölüm 3 'te yer verilmiş̧ir.

Tablo 1. Sağlık sektöründe gerçekleştirilen simülasyon çalışmaları

\begin{tabular}{|l|l|l|l|l|l|}
\hline \multicolumn{2}{|l|}{ Acil Servis } \\
\hline $\begin{array}{l}\text { Yayın } \\
\text { Yılı }\end{array}$ & Yazar & Ülke & Kullanılan Yöntemler & Ele Alınan Problem & Sonuçlar \\
\hline 2008 & Hoot ve diğ. & & Talep tahmini simülasyonu & ASb kalabalıklaşma & $\begin{array}{l}\text { Öngörülen ve fiili çalışma koşulları arasındaki ilişkiyi } \\
\text { incelemişlerdir. }\end{array}$ \\
\hline 2008 & Khurma ve diğ. & & ProModel yazılım simülasyonu & ASb işlemlerinin verimliliği & Verimliliği belirli ölçüde artırmışlardır. \\
\hline 2012 & Zeng ve diğ. & $\begin{array}{l}\text { Lexin- } \\
\text { gton, } \\
\text { Ken- } \\
\text { tucky, } \\
\text { ABD }\end{array}$ & $\begin{array}{l}\text { SIMUL8 yazılımını kullana- } \\
\text { rak AOS }\end{array}$ & $\begin{array}{l}\text { ASb’nin potansiyel kullanımının ve- } \\
\text { rimliliği }\end{array}$ & $\begin{array}{l}\text { Ortalama bekleme süresini \%13, kalış süresini \%5 ve } \\
\text { hasta kayıplarını \%25 oranında azaltmayı başarmış- } \\
\text { lardır. }\end{array}$ \\
\hline 2014 & $\begin{array}{l}\text { Al-Refaie ve } \\
\text { diğ. }\end{array}$ & Ürdün & $\begin{array}{l}\text { Simülasyon ve Veri Zarflama } \\
\text { Analizi }\end{array}$ & $\begin{array}{l}\text { ASb için kapasite, maliyet ve mevcut } \\
\text { kaynak kısıtı }\end{array}$ & $\begin{array}{l}10 \text { olası çalışma senaryosu arasından en iyi senaryoyu } \\
\text { seçmişlerdir. }\end{array}$ \\
\hline
\end{tabular}




\begin{tabular}{|c|c|c|c|c|c|}
\hline 2014 & Best ve diğ. & Gana & $\begin{array}{l}\text { Arena Simülasyon Yazılımını } \\
\text { kullanarak AOS }\end{array}$ & Hasta sayısının artırılması & $\begin{array}{l}\text { Ek kaynakların etkilerini ve kapasite tahsisinde mey- } \\
\text { dana gelen değişiklikleri analiz ederek acil sağlık sis- } \\
\text { temi için kalma süresini azaltarak hasta akışını geliştir- } \\
\text { diğini göstermişlerdir. }\end{array}$ \\
\hline 2014 & $\begin{array}{l}\text { Radhakrishnan } \\
\text { ve diğ. }\end{array}$ & & AOS & $\begin{array}{l}\text { Hasta sırasını azaltmak, zamandan ta- } \\
\text { sarruf etmek, operasyon maliyetlerini } \\
\text { azaltmak ve çeşitli sağlık birimleri ara- } \\
\text { sındaki iletişimi artırmak }\end{array}$ & $\begin{array}{l}\text { İstenilen amaçlara ulaşmak için giyilebilir sağlık izleme } \\
\text { sistemini önermişlerdir. }\end{array}$ \\
\hline 2015 & Lin ve diğ. & & $\begin{array}{l}\text { Üç farklı AY stratejisine sahip } \\
\text { simülasyon modeli }\end{array}$ & AY stratejilerini belirleme & $\begin{array}{l}\text { AY aralıklarını, AY başlangıç ölçütlerini analiz etmiş- } \\
\text { lerdir. }\end{array}$ \\
\hline 2016 & Azadeh ve diğ. & İran & $\begin{array}{l}\text { Veri Zarflama Analizi ve Awe- } \\
\text { Sim yazılımını kullanarak AOS }\end{array}$ & $\begin{array}{l}\text { ASb'nin hizmet kalitesini iyileştirmek } \\
\text { (bekleyen hasta sayısını azaltmak ve } \\
\text { hataları tespit etmek) }\end{array}$ & $\begin{array}{l}\text { ASb'nin toplam performansının iyileştirilebileceği ka- } \\
\text { nıtlamışlardır. }\end{array}$ \\
\hline 2016 & $\begin{array}{l}\text { Ünlüyurt \& Tun- } \\
\text { çer }\end{array}$ & İstanbul & AOS & Ambulansların kullanım verimliliği & $\begin{array}{l}\text { En yakın ambulansın yoğun olduğu durumda müsait } \\
\text { olan başka bir ambulansın yönlendirilebileceği determi- } \\
\text { nistik ambulans yeri modelini önermişlerdir. }\end{array}$ \\
\hline \multicolumn{6}{|c|}{ Ayakta Tedavi Bölümü } \\
\hline $\begin{array}{l}\text { Yayın } \\
\text { Yllı } \\
\end{array}$ & Yazar & Ülke & Kullanılan Yöntemler & Ele Alınan Problem & Sonuçlar \\
\hline 2007 & Coelli ve diğ. & & $\begin{array}{l}\text { Medmode } 6.0 \text { yazılımını kulla- } \\
\text { narak AOS }\end{array}$ & Bir mamografi taramasının analizi & $\begin{array}{l}\text { Beklenen hasta akış hızını göz önünde bulundurarak } \\
\text { verimliliğin artırılmasına yönelik stratejinin belirlenme- } \\
\text { sine odaklanmışlardır. }\end{array}$ \\
\hline 2007 & Kapamara & İngiltere & $\begin{array}{l}\text { Simul8 yazılımını kullana- } \\
\text { rak AOS }\end{array}$ & $\begin{array}{l}\text { Hastalar ve ekipman olanakları arasın- } \\
\text { daki ilişkideki darboğaz ve komplikas- } \\
\text { yonları ve hasta akışını incelemek } \\
\end{array}$ & $\begin{array}{l}\text { Hastalar ve ekipman olanakları arasındaki ilişkideki } \\
\text { darboğaz ve komplikasyonları belirlemeyi, bununla be- } \\
\text { raber hasta akışlarını araştırmaya odaklanmıştır. }\end{array}$ \\
\hline 2009 & J. Klassen & & \begin{tabular}{|l|} 
Simülasyon tabanlı optimizas- \\
yon modeli
\end{tabular} & $\begin{array}{l}\text { En iyi sonuç veren randevu çizelgesini } \\
\text { belirlemek }\end{array}$ & $\begin{array}{l}\text { Daha fazla değişkeni ve çevresel faktörleri dikkate ala- } \\
\text { bilen bir model önermişlerdir. }\end{array}$ \\
\hline 2011 & $\begin{array}{l}\text { Villamizar ve } \\
\text { diğ. }\end{array}$ & Brezilya & AOS & $\begin{array}{l}\text { Bir fizyoterapi kliniğinin performan- } \\
\text { sinı incelemek }\end{array}$ & $\begin{array}{l}\text { 1. Aşama: Yeni sistemi simülasyon tekniği ile analiz etmiş- } \\
\text { lerdir. } \\
\text { 2. Aşama: Senaryo analizi ile hasta sayısııı, personel sayı- } \\
\text { sını ve hastaların varış zamanlarını analiz etmişlerdir. }\end{array}$ \\
\hline 2011 & Rohleder ve diğ. & Kanada & AOS & Hasta bekleme sürelerini iyileştirmek & Hasta bekleme sürelerini kısaltmayı başarmışlardır. \\
\hline 2012 & $\begin{array}{l}\text { Masselink ve } \\
\text { diğ. }\end{array}$ & Hollanda & AOS & $\begin{array}{l}\text { Hasta bekleme süresi ve eczane politi- } \\
\text { kaları arasındaki ilişkiyi incelemek }\end{array}$ & $\begin{array}{l}\text { Bekleme süresinin yarı yarıya azaltılmasıyla eczane mali- } \\
\text { yetlerinin \%1-2 oranında arttığını ortaya koymuşlardır. }\end{array}$ \\
\hline 2014 & Baril ve diğ. & & \begin{tabular}{|l|} 
Kaynak planlama, randevu be- \\
lirleme kuralları ve hasta geliş- \\
leri arasındaki ilişkiyi inceleyen \\
bir AOS \\
\end{tabular} & $\begin{array}{l}\text { Ortopedi kliniğinin performansını de- } \\
\text { ğerlendirmek }\end{array}$ & $\begin{array}{l}\text { Ortalama hasta bekleme sürelerini azaltmayı başarmış- } \\
\text { lardır. }\end{array}$ \\
\hline 2014 & Peng ve diğ. & & $\begin{array}{l}\text { MATLAB programinda kodla- } \\
\text { nan AOS-GA }\end{array}$ & $\begin{array}{l}\text { Açık erişim klinikleri ve randevusuz } \\
\text { hastalar için en uygun çizelgeyi tasar- } \\
\text { lamak }\end{array}$ & $\begin{array}{l}\text { Randevuların optimal yüzdesini ve optimal tahsisini } \\
\text { bulmuşlardır ve bahsedilen iki tip hastaların başvuru } \\
\text { başına ödediği ortalama maliyeti önerilen yöntemle } \\
\text { azaltmışlardır. }\end{array}$ \\
\hline 2016 & $\begin{array}{l}\text { Ben-Towim ve } \\
\text { diğ. }\end{array}$ & \begin{tabular}{|l|} 
Güney \\
Avust- \\
ralya \\
\end{tabular} & HOBMTE & Hasta akışını incelemek & $\begin{array}{l}\text { Tüm hastaneyi ayrıntılı bir şekilde temsil eden bir mo- } \\
\text { del önermişlerdir. }\end{array}$ \\
\hline 2016 & Baril ve diğ. & Kanada & AOS ve Yalın Yönetim & Hizmet sunum süreçlerini geliştirmek & $\begin{array}{l}\text { Bir Hematoloji-Onkoloji ayakta tedavi bölümündeki } \\
\text { hastaların akışını iyileştirmişleridir. }\end{array}$ \\
\hline 2017 & $\begin{array}{l}\text { Babashov ve } \\
\text { diğ. }\end{array}$ & Kanada & $\begin{array}{l}\text { Simul8 yazılımını kullana- } \\
\text { rak, AOS }\end{array}$ & \begin{tabular}{|l|} 
Hasta bekleme sürelerini kısaltmak için \\
tüm radyasyon tedavisi planlama süre- \\
cini incelemek
\end{tabular} & $\begin{array}{l}\text { Hasta bekleme sürelerini ciddi oranda iyileştirmeyi ba- } \\
\text { şarmışlardır. Ayrıca bu model ile mevcut hizmet kalite- } \\
\text { sinin arttırllabileceğini de belirtmişlerdir. }\end{array}$ \\
\hline \multicolumn{6}{|c|}{ Yatarak Tedavi Bölümü } \\
\hline $\begin{array}{l}\text { Yayın } \\
\text { Yllı } \\
\end{array}$ & Yazar & Ülke & Kullanılan Yöntemler & Ele Alınan Problem & Sonuçlar \\
\hline 2013 & Kim ve diğ. & & AOS & $\begin{array}{l}\text { Personelin değişen çalışma koşullarını } \\
\text { analiz etmek }\end{array}$ & $\begin{array}{l}\text { Bu senaryoların sonuçlarını mevcut sistemle karşılaş- } \\
\text { tırmışlardır. }\end{array}$ \\
\hline 2014 & $\begin{array}{l}\text { Chemweno ve } \\
\text { diğ. }\end{array}$ & Belçika & $\begin{array}{l}\text { ARENA yazilımını kullana- } \\
\text { rak AOS }\end{array}$ & $\begin{array}{l}\text { İnme geçiren hastaların yatış sürelerini } \\
\text { analiz etmek }\end{array}$ & $\begin{array}{l}\text { Klinikte hasta akışları ve yatak kapasitesi problemlerine } \\
\text { odaklanmışlardır. }\end{array}$ \\
\hline
\end{tabular}




\begin{tabular}{|c|c|c|c|c|c|}
\hline 2015 & $\begin{array}{l}\text { Devapriya ve } \\
\text { diğ. }\end{array}$ & & AOS & $\begin{array}{l}\text { Yatak kapasitesi, hasta bekleme süre- } \\
\text { leri, hastaların doluluk oranı ve mali- } \\
\text { yetleri gibi sorunları incelemek }\end{array}$ & $\begin{array}{l}\text { Stratejik yatak analiz modeli ile mevcut sağlık sistemi } \\
\text { kapasitesinin nasıl arttırılabileceği incelenmiştir. }\end{array}$ \\
\hline \multicolumn{6}{|c|}{ Diğer Hasta Birimleri } \\
\hline $\begin{array}{l}\text { Yayın } \\
\text { Yılı }\end{array}$ & Yazar & Ülke & Kullanılan Yöntemler & Ele Alınan Problem & Sonuçlar \\
\hline 2011 & Reynolds ve diğ. & Londra & ExtendSim kullanılarak AOS & $\begin{array}{l}\text { Hastane bünyesinde hizmet veren iki } \\
\text { eczanenin iş yükünü incelemek }\end{array}$ & $\begin{array}{l}\text { Sisteme yeni bir eczacının eklenmesi, günlük iş yü- } \\
\text { künde } \% 10^{\prime} l u k \text { ve aynı zamanda geri dönüş sürelerinde } \\
\% 20 \text { 'lik bir düşüşe neden olmuştur. }\end{array}$ \\
\hline 2016 & Dan ve diğ. & Çin & AOS & Hasta bekleme sorununu incelemek & Simülasyon sonuçlarına göre ana problem keşfedilmiştir \\
\hline 2017 & $\begin{array}{l}\text { Rodrigues ve } \\
\text { diğ. }\end{array}$ & & AOS & $\begin{array}{l}\text { Yoğun bakım ünitelerinde ve yatarak } \\
\text { tedavi bölümündeki karmaşık hasta akı- } \\
\text { şını incelemek }\end{array}$ & $\begin{array}{l}\text { Hasta maliyetlerini günde } \% 18 \text { 'e kadar düşürebilmiş- } \\
\text { lerdir. }\end{array}$ \\
\hline
\end{tabular}

\section{AMELIYATHANE ÇIZELGELEME SÜREÇLERINDE GERÇEKLEŞTİRILEN SIMÜLASYON ÇALIŞMALARI}

Hastanelerdeki ameliyathane çizelgeleme süreçleri, yüksek düzeyde belirsizlik ve kaynak kısıtlarını içeren; daha da önemlisi, hastaların bekleme süreleri insan hayatına bile mal olabileceğinden, dikkatli bir şekilde planlanması gereken çok karmaşık ve maliyetli bir süreç olarak karşımıza çıkmaktadır. Ameliyathane çizelgeleme süreçlerinin planlamasını etkileyen birçok faktör vardır. Ameliyat yapmak için gerekli kaynaklar, ameliyathane personeli (cerrahlar, anestezistler, hemşireler, vb.), özel donanımlar, ameliyathaneler, anestezi sonrası bakım üniteleri ve yoğun bakım üniteleri olarak ele alınabilir. Ameliyathane çizelgeleme süreçlerinin planlanmasını etkileyen diğer bir faktör de bazı ameliyatlar planlanabilirken, diğerlerinin acil durumlarda ve ani müdahale durumlarında planlanmasında zorluk yaşanabilmesidir. Bu süreç aynı zamanda tedarik süreci, iyileşme süreci, ameliyatlar, acil hasta varış ve sağlık personelinin uygunluğu gibi pek çok belirsizlik içermektedir. Bu belirsizlikler, ameliyathane ekibi için bekleme süresi, ameliyathanenin boşalması, fazla mesai, verimlilik ve bakım kalitesi gibi birçok soruna da neden olmaktadır. Tüm bu faktörleri ve belirsizlikleri aynı anda ele almak sorunu daha da karmaşıklaştırabilmektedir. Sonuç olarak, tüm bu parametreleri ele alan modelleri çözmek zor ya da imkânsızlaşabilmektedir. Modelin yapısının zorluğundan dolayı literatürde bu konu bölümlere ayrılmıştır ve sadece acil ameliyatların planlanması veya programlanması çalışılmıştır. Tüm sistemle ilgilenen çalışmalarda genellikle problemin karmaşıklığı nedeniyle modeli çözmek için sezgisel yöntemler veya simülasyon teknikleri kullanılmıştır.

$\mathrm{Bu}$ çalışma kapsamında ameliyathane süreçlerinin çizelgelenmesi problemi, hasta, ameliyat ve kaynak üzerine odaklanılarak üç kategoride ele alınmıştır. Ayrıca kaynak çizelgeleme modelleri, personel (cerrah, hemşire ve diğer personel) ve ekipman/donanım olarak 2 grupta ele alınmıştır.
İncelenen ameliyathane çalışmalarının sınıflandırmasına Şekil 2'de yer verilmiştir.

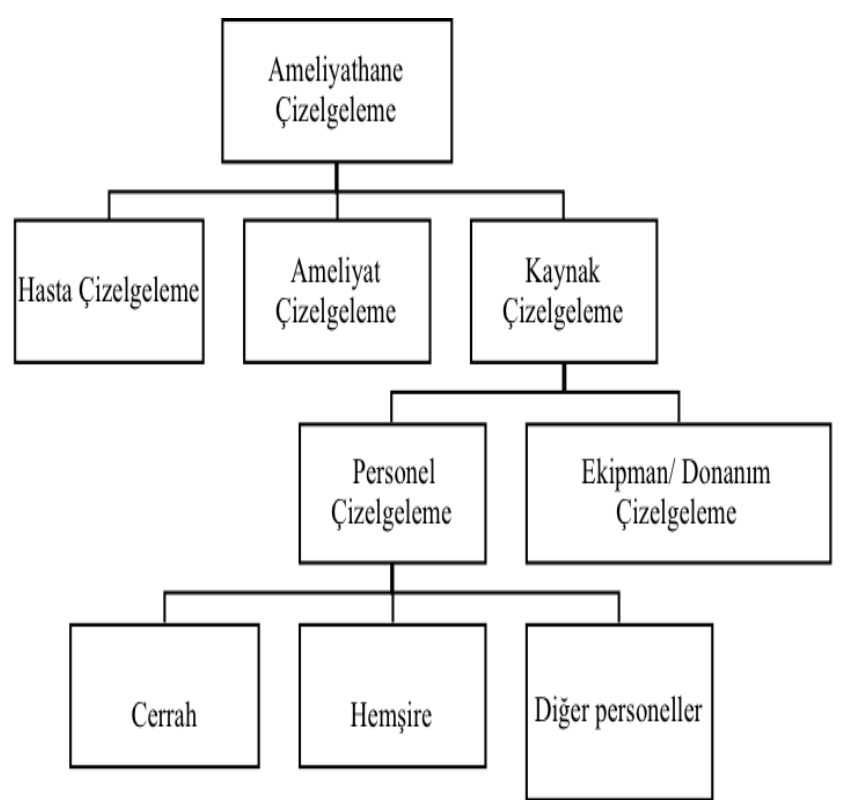

Şekil 2. Ameliyathane çalışmalarının sınıflandırılması

Ayrıca, fazla mesai, hasta bekleme süreleri, hastaya bağ maliyetler, ameliyatın iptal edilmesi, hastaların ameliyata hazırlanma süresi, ameliyatların tahlilleri, ameliyathanelerin dolması, hasta akışındaki darboğazlar, kaynakların aşırı kullanımı, geç kalınan ameliyat tarihleri ve atanan yatakların uyumsuzluklarından kaynaklanan cezalar, iyileşme bölümü yataklarının tahsisi ve maliyetlerinin en aza indirilmesi; yatak doluluk oranları, planlanan ameliyat sayısı, ameliyathane kullanımı, hizmet verilen hasta sayısının maksimizasyonu gibi modellerin ana amaçlarına dayanan bir başka sınıflandırma grubu daha oluş̧urulmuştur. Çalışma kapsamında önerilen ana hedef sınıflandırma şemasına Şekil 3 'te yer verilmiştir. 

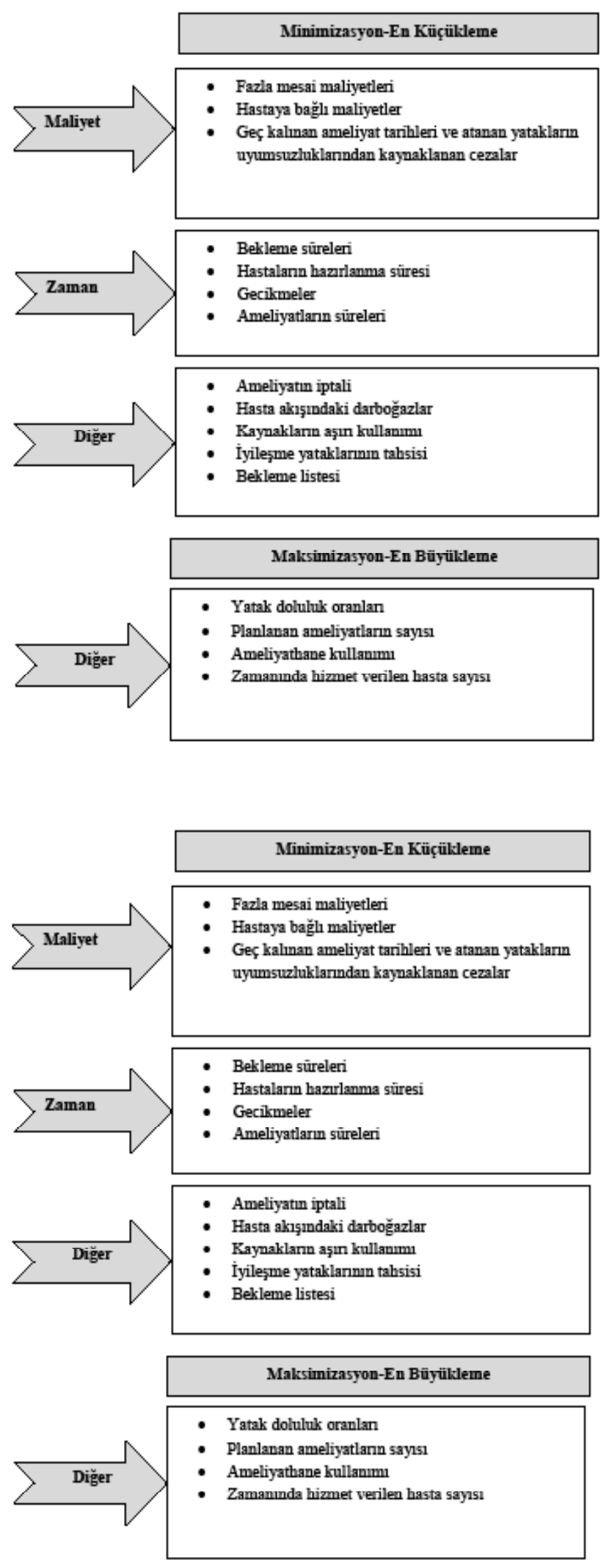

Şekil 3. Ameliyathane çizelgeleme çalışmalarının ana hedeflerinin siniflandirılması

\subsection{Hasta Çizelgeleme}

İlk çalışma grubu, ameliyathanelerde uygulanan hasta çizelgeleme çalışmalarını içermektedir. Ameliyathane çizelgeleme çalışmaları, aynı zamanda hasta çizelgeleme modellerinde incelenen ayakta tedavi edilen hastalar için de kullanılmaktadır. Bu gruptaki çalışmaların çoğu, hasta bekleme süresinin, iptal edilen ameliyat sayılarının, hastaya bağlı maliyetlerin, fazla mesai masraflarının minimizasyonunu ve belirtilen süre içinde hizmet verilen hasta miktar1nın maksimizasyonunu hedeflemiştir.

Lamiri ve diğ. (2007) planlı ve acil ameliyatları göz önünde bulundurarak ameliyathane çizelgeleme problemi için bir matematiksel model önermişlerdir. Önerilen modelin amacı, seçilmiş hastalarının işletme maliyetlerini ve ameliyathanenin fazla mesai ücretlerinin toplamını azaltmaktır. Çözüm yöntemi olarak, Monte-Carlo Simülasyonu ve Sütun Ekleme yöntemlerini birleştiren bir yaklaşımı önermişlerdir. Lamiri ve diğ . (2009) ise daha sonra bu modeli geliştirmişlerdir.

Persson \& Persson (2010) belirsiz hasta talebi ve ameliyat sürelerini dikkate alarak ameliyathane yönetim politikasını iyileştirmek için bir model önermişlerdir. Önerdikleri farklı politikaların, hasta bekleme sürelerini, operasyon iptalleri ve ameliyathane kullanımlarını nasıl etkilediğini analiz etmek için simülasyon tekniği kullanmışlardır. Bekleme olasılıklarına dayalı olarak öncelik verilen hastaları dikkate alan ameliyatları acil veya acil olmayan şeklinde sınıflandırarak planlamışlardır. Ayrıca, ameliyatların gerçek ve beklenen sürelerinin etkisini de analiz etmişlerdir. Beklenen ameliyat süreleri geçmiş verilerden toplanırken, gerçek ameliyat süreleri logaritmik normal olasılık dağılımına göre elde edilmiştir. Acil durumlar için ameliyathane ayırmanın ve personel sayısını artırmanın ameliyathanelerin performansını artırmaya yardımcı olduğunu göstermişlerdir. Önerilen modeli geliştirmek için İsveç’teki Blekinge Hastanesindeki Ortopedi bölümünde yapılan ameliyatların verilerini kullanılmıştır.

Niu ve diğ. (2011), Winnipeg Sağlık Bilimleri Merkezi'ndeki ameliyathanelerdeki hasta akışındaki darboğazları bulmak için bir simülasyon modeli önermişlerdir. Ameliyathane'nin simülasyon modelini oluşturmak için WITNESS yazılımını kullanmışlardır. Önerilen modelde seçilmiş acil hastaların ameliyat planını ele almışlardır. Bunun yanı sıra tüm ameliyathane sistemini simülasyona eklemek için Anestezi Sonrası Bakım Ünitesini ve Cerrahi Yoğun Bakım Ünitesini de modele dahil etmişlerdir.

Chow ve diğ. (2011), cerrahi servislerinde yatak doluluk oranlarındaki değişimleri azaltan hem cerrrahları hem de hasta tiplerini dikkate alan ameliyat çizelgesi oluşturmak 
adına Monte - Carlo simülasyonu ve karma tamsayılı programlama modellerinin kombinasyonunu olan bir yöntem önermişlerdir. Literatürde yer alan diğer simülasyon modelleri ile karşılaştırıldığında, önerilen yazılımın kullanıcı dostu arayüzü, MS Excel tabanlı olma özelliği ve eğer/ne (what/if) analizleri yapabilme özelliği dikkat çekmektedir.

Gul ve diğ. (2011), ameliyathane çizelgeleme problemini simülasyon modeli, iki ölçütlü genetik algoritma yöntemi ve senaryo analizi olmak üzere üç aşamada ele almışladır. Önerilen modelin amacı, hasta bekleme sürelerini, kaynakların aşırı kullanımını ve fazla mesai masraflarını en aza indirmektir. Simülasyon modelini kullanarak farklı s1ralama ve hasta randevu zamanlarını analiz etmişlerdir. Çözüm yöntemi olarak iki kriterli genetik algoritma yöntemini önermişler ve farklı değişkenler göz önünde bulundurularak kullanılan genetik algoritma yönteminin etkinliğini araştırmışlardır.

Batun ve diğ. (2011) ameliyathane çizelgeleme problemi için bir karma tamsayılı programlama modeli önermişlerdir. Önerilen model, her gün kaç tane ameliyathanenin açık olması gerektiğine dair kararları, her bir ameliyathane içindeki ameliyat sırasını ve her cerrahın başlangıç zamanını içermektedir. Ameliyat öncesi kesi, kesi ve kesi sonrasını içeren ameliyat süresini hesaplamak için bir AOS modeli kurgulamışlardır. Önerilen modelde ameliyathaneler ve cerrahlar önerilen modelde kaynak olarak kullanılırken, hastalar varlık olarak kullanılmıştır.

Saremi ve diğ. (2012), çoklu kaynakların kullanılabilirliğini, hasta tipi ve cerrah uzmanlığı uyumluluğunu göz önünde bulunduran bir model önermişledir. Ameliyat iptallerini, ameliyatların tamamlanma sürelerini, hastaların bekleme sürelerini azaltmayı hedeflemişlerdir. Ameliyat tiplerini çizelgelemek için simülasyon tabanlı tabu arama yöntemini geliştirmişlerdir.

Aringhieri ve di g. (2015), her bir zaman dilimi içinde çizelgelenen hastaları göz önünde bulundurarak ameliyathane ve iyileşme yataklarının çizelgelenmesi problemi üzerinde çalışmışlardır. Önerilen modelin literatüre en önemli katkısı, hafta sonu yatış yapması gereken hastaların modele eklenmiş olmasıdır. Hastaların bekleme sürelerini azaltmayı ve iyileşme yataklarının kullanım verimliliğini artırmayı amaçlamışlardır. Problemin polinomsal zamanda bir çözümünün olmaması (NP-Hard) nedeniyle, modeli çözmek için iki seviyeli sezgisel bir çözüm yöntemi önermişlerdir. Önerilen yöntem, İtalya'nın Cenova kentinde bulunan bir kamu hastanesinin Genel Cerrahi servisinde toplanan veriler kullanılarak sayısal olarak test edilmiş ve doğrulanmıştır.

Saadouli ve diğ. (2015) ameliyat sürelerinin, iyileşme sürelerinin ve kaynak kapasitelerinin belirsizliği göz önünde bulundurularak hasta çizelgeleme problemi için bir karma tamsayılı programlama algoritması önermişlerdir. Bu belirsizlikler ile başa çıkmak için iki fazlı modeller kullanmışlardır. Seçilmiş ameliyatları, gecikmeleri en aza indirmek için bir karma tamsayılı model kullanarak ameliyathaneye atamışlardır. Çalışma kapsamında mevcut strateji ile önerilen stratejinin performansını karşılaştırmak için simülasyon modeli kullanmışlardır.

Astaraky \& Patrick (2015) hasta talebi ile ameliyat tarihi arasındaki süreyi, ameliyathanede yaşanabilecek fazla mesai durumunu ve sistemde yaşanacak darboğaz nedeniyle oluşabilecek hasta bekleme sürelerini en aza indiren, Markov Karar Süreci ile ilgili problemi ele alan bir model ve çözüm yöntemi ortaya koymuşlardır. Bu çalışmanın literatüre en önemli katkısı hem ameliyathanenin hem de iyileşme yataklarının kullanım verimliğinin dikkate alan bir ana cerrahi çizelgeleme yaratmasıdır. Önerilen politikanın başarısını göstermek için yerel bir hastaneden elde edilen verilerle model test edilmiştir.

Duma \& Aringhieri (2015), ameliyatların iptallerine, gecikmelere ve fazla mesailere neden olan hastalar için gerçek zamanlı ameliyathane çizelgelemesi ile ilgilenmişlerdir. Gerçek zamanlı yönetim için çevrim içi optimizasyon yöntemini ve ameliyat tipi çizelgelemesi için de ek optimizasyon tekniklerini önermişlerdir. Modeli çözmek için melez bir simülasyon tekniğini önermişlerdir. Gerçek zamanlı hasta akışını sağlamak için gerçek zamanlı yönetim stratejisinde kullanılan çevirim içi yaklaşım ve rassallık ile başa çıkmak için simülasyon tekniklerini kullanmışlardır.

Landa ve diğ. (2015), ameliyat çizelgeleme problemini "ileri çizelgeleme" ve "atama çizelgeleme" olmak üzere iki kategoride ele almışlardır. Birinci kategoride, ameliyat tarihlerini belirlemişlerdir ve ikinci aşama olarak da hasta akışını bir sıra halinde belirlemişlerdir. İşlem sürelerinin, bilinen bir dağılım olarak rastgele bir değişken olduğunu varsaymışlardır. Her bir alt problemi çözmek için tamsayılı doğrusal programlama ve tüm problemi çözmek için Monte-Carlo simülasyonu ile komşuluk arama tekniklerinin karması olan iki aşamalı bir iyileştirme algoritması önermişlerdir. Ameliyathanelerin kullanımını artırmayı ve hasta iptallerini azaltmayı amaçlamışlardır.

Samudra ve diğ. (2017) Belçika Leuven Üniversite Hastanesi'nde var olan hasta çizelgeleme problemi için gerçekçi bir simülasyon modeli önermişlerdir. Oluşabilecek sağlık risklerini azaltabilmek için hasta bekleme sürelerini azaltmayı hedeflemişlerdir. Planlı olmayan hasta gelişlerinin çizelgelenmesi kararını da modele ekleyerek literatüre katkıda bulunmuşlardır ve böylelikle ameliyat zamanından önce hasta çizelgeleme planını yeniden oluşturmayı 
amaçlamışlardır. Önerilen modelin performansını farklı çizelgeleme stratejileri ve senaryo analizleri kullanarak analiz etmişlerdir.

\subsection{Operasyon Çizelgeleme}

İkinci çalışma grubunu, ameliyathanelerde uygulanan operasyon çizelgeleme çalışmalarını içermektedir. Banditori ve diğ. (2013) ameliyathane odası, ameliyat sonrası yatak gibi kaynakların kullanılabilirliğini göz önünde bulundurarak, karma tamsayılı programlama, ana cerrahi planlama problemini ele almışlardır. Bekleyen hastaları sınıflandırmak için ameliyatları gruplandırmışlardır. Planlanan ameliyat sayısını en büyüklemek için, gecikmeler ve yatak uyumsuzluklarından kaynaklanan cezaları en aza indirmeyi hedeflemişlerdir. Karma tamsayılı programlama optimizasyonu ve AOS yaklaşımı kullanarak modeli çözmüşlerdir. Önerilen modelin uygulaması, İtalya'nın Floransa kentindeki Meyer Üniversitesi Çocuk Hastanesi'nin verileri ile yapılmıştır. Xiang (2017) çok amaçlı ameliyathane çizelgeleme probleminin çözümü için Pareto çözüm setleri ve Karınca Kolonisi Optimizasyonu yaklaşımını içeren meta-sezgisel bir yöntem önermişlerdir. Önerilen yöntem, M.D. Anderson Kanser Merkezi'ne ait veriler üzerinde test edilmiştir ve elde edilen hesaplama sonuçları söz konusu yöntemin çizelge tamamlanma zamanını kısaltmada, hemşirelerin fazla mesai sayısını azaltmada ve genel olarak kaynakların dengelenmesinde iyi sonuçlar elde ettiğini göstermiştir.

\subsection{Kaynak Kısıtlı Çizelgeleme}

Üçüncü çalışma grubunu, ameliyathanelerde uygulanan kaynak kısıtlı çizelgeleme çalışmaları oluşturmaktadır. $\mathrm{Bu}$ gruptaki çalışmalar, genellikle personel (cerrahlar veya hemşireler) atama için genetik modelleri ile ilgilenmiş ve bazı çalışmalar da hasta yatakları ve açık ameliyat odaları gibi kısıtlı kaynaklar dikkate almıştır.

Van Oostrum ve diğ. (2008) ameliyathanede gece gerçekleşen ameliyatlar için personel çizelgeleme problemi üzerinde çalışmışlardır. Cerrahların, ameliyathane ve anestezi hemşirelerinin ve diğer personeli dikkate alan bir simülasyon modeli önermişlerdir. Önerilen modelde kullanılan veriler, Erasmus Üniversitesi Tıp Merkezi hasta giriş verilerinden (acil durum hastalarının geliş zamanları, ameliyatların süreleri, hastaların anestezi sonrası bakım ünitesinde kalma süresi ve nakil süreleri) toplanmıştır. Problemin karmaşı yapısı ve büyüklüğü nedeniyle ilk olarak ameliyathane kullanımını en üst düzeye çıkaran ve daha sonra servis ve yoğun bakım üniteleri gibi diğer hastane birimlerine olan talepleri dikkate alan iki aşamalı bir sütun oluşturma yaklaŞımını çözüm yöntemi olarak önermişlerdir.

Arnaout \& Kulbashian (2008), ameliyathane odalarının kullanımını en büyüklerken, ameliyatın tamamlanma zamanını en küçüklemeyi amaçlayan bir paralel makine çizelgeleme problemi tanımlamışlardır. Ele aldıkları problem, ameliyat süreçlerinin ve hazırlık sürelerinin belirsizliklerine sahiptir. Önerilen modeli, En Uzun İşlem Süresi, En Kısa İşlem Süresi, En Uzun Beklenen İşlem Süresi, En Kısa Beklenen İşlem Süresi, simülasyon tekniği kullanılarak Hazırlık Süresi ile En Uzun Beklenen İşlem süresi gibi farklı işlem süresi stratejilerini dikkate alan buluşsal algoritmalar ile çözmüşlerdir.

M'Hallah \& Al-Roomi (2014) bloklamalı çizelgeleme stratejisini kullanarak seçilmiş cerrahi vakalar için ameliyathane çizelgeleme problemini ele almışlardır. Ameliyathane çizelgeleme problemini, çevirim içi ve çevirim dışı olmak üzere iki kategoride değerlendirmişlerdir. Önerilenler arasında en iyi stratejiyi bulmak için kullanıcı dostu bir simülasyon modeli önermişlerdir. Ameliyathanenin aşırı iş yükünü azaltmak için ameliyatın çevrimiçi seviyede iptal edilmesi ve iş yükünün çevrimdışı seviyede sınırlandırılması olarak iki strateji önermişlerdir.

Molina-Pariente ve diğ. (2018), belirsiz ameliyat süreleri ve öngörülemeyen acil ameliyatları dikkate alarak, süre ve kapasite kısıtlarının aşılmasının yaratacağı maliyeti en küçüklemeyi hedeflemişlerdir. Çözüm yöntemi olarak yen Monte-Carlo simülasyon yöntemini yerel bir arama algoritması ile birleştirmişlerdir. Yazarlar elde edilen sonuçları problemin deterministik çözümü ile karşılaştırarak önerilen yöntemin maliyetleri azalttı̆̆ını göstermişlerdir.

Derleme çalışması kapsamında taranan, ameliyathane çizelgeleme süreçlerinde gerçekleştirilen simülasyon çalışmaları yayın yılı, yazar, ülke, kullanılan yöntemler, ele alınan problem ve sonuçlar bilgileri ile birlikte Tablo 2'de özetlenmiştir. 
Tablo 2. Ameliyathane çizelgeleme süreçlerinde gerçekleştirilen simülasyon çalışmaları

\begin{tabular}{|c|c|c|c|c|c|}
\hline \multicolumn{6}{|c|}{ Hasta Çizelgeleme } \\
\hline \begin{tabular}{|l|} 
Yayın \\
Yılı
\end{tabular} & Yazar & Ülke & Kullanılan Yöntemler & Ele Alınan Problem & Sonuçlar \\
\hline $\begin{array}{l}2007- \\
2009\end{array}$ & $\begin{array}{l}\text { Lamiri ve } \\
\text { diğ. }\end{array}$ & & $\begin{array}{l}\text { Monte-Carlo Simülasyonu ve Sütun } \\
\text { Ekleme Yöntemi }\end{array}$ & $\begin{array}{l}\text { Planlı ve acil ameliyatları göz önünde } \\
\text { bulundurarak ameliyathane çizelge- } \\
\text { leme }\end{array}$ & $\begin{array}{l}\text { Seçilmiş hastalarının işletme maliyetlerini } \\
\text { ve ameliyathanenin fazla mesai ücretlerinin } \\
\text { toplamını azaltmışlardır. }\end{array}$ \\
\hline 2010 & $\begin{array}{l}\text { Persson \& } \\
\text { Persson }\end{array}$ & İsveç & AOS & $\begin{array}{l}\text { Belirsiz hasta talebi ve ameliyat süre- } \\
\text { lerini dikkate alarak ameliyathane yö- } \\
\text { netim politikasını iyileştirmek }\end{array}$ & $\begin{array}{l}\text { Acil durumlar için ameliyathane ayırmanın } \\
\text { ve personel sayısını artırmanın ameliyatha- } \\
\text { nelerin performansını arttırmaya yardımcı } \\
\text { olduğunu göstermişlerdir. }\end{array}$ \\
\hline 2011 & Niu ve diğ. & Kanada & $\begin{array}{l}\text { WITNESS yazılımını kullanarak } \\
\text { AOS modeli }\end{array}$ & $\begin{array}{l}\text { Ameliyathanelerdeki hasta akışındaki } \\
\text { darboğazlar }\end{array}$ & $\begin{array}{l}\text { Tüm ameliyathane sistemini simülasyona } \\
\text { eklemek için Anestezi Sonrası Bakım Üni- } \\
\text { tesini ve Cerrahi Yoğun Bakım Ünitesini } \\
\text { modele dahil ederek seçilmiş acil hastaların } \\
\text { ameliyat planını ele almışlardır. } \\
\end{array}$ \\
\hline 2011 & $\begin{array}{l}\text { Chow ve } \\
\text { diğ. }\end{array}$ & Kanada & $\begin{array}{l}\text { Monte-Carlo simülasyon modeli ile } \\
\text { karma tamsayılı optimizasyon modeli }\end{array}$ & $\begin{array}{l}\text { Hem cerrahları hem de hasta tiplerini } \\
\text { çizelgeleme }\end{array}$ & $\begin{array}{l}\text { Maksimum yatak doluluğunu en aza indir- } \\
\text { meyi başarmışlardır. }\end{array}$ \\
\hline 2011 & Gul ve diğ. & \begin{tabular}{|l} 
Min- \\
nesota, \\
ABD \\
\end{tabular} & $\begin{array}{l}\text { Simülasyon modeli, iki ölçütlü bir } \\
\text { genetik algoritma ve senaryo analizi }\end{array}$ & Ameliyathane çizelgeleme & $\begin{array}{l}\text { Hasta bekleme sürelerini, kaynakların aşıı } \\
\text { kullanımını ve fazla mesai masraflarını en } \\
\text { aza indirgemişlerdir. }\end{array}$ \\
\hline 2011 & $\begin{array}{l}\text { Batun ve } \\
\text { diğ. }\end{array}$ & $\begin{array}{l}\text { Min- } \\
\text { nesota, } \\
\text { ABD }\end{array}$ & $\begin{array}{l}\text { AOS, iki aşamalı - rassal karma tam- } \\
\text { say1lı programlama ve } \\
\text { Ameliyathane odası gruplama (Ope- } \\
\text { rating Room Pooling) }\end{array}$ & Ameliyathane çizelgeleme & $\begin{array}{l}\text { Toplam tahmin edilen operasyon maliyetini } \\
\text { azaltmayı amaçlamışlardır. }\end{array}$ \\
\hline 2012 & $\begin{array}{l}\text { Saremi ve } \\
\text { diğ. }\end{array}$ & Kanada & $\begin{array}{l}\text { ARENA yazılımını kullanarak, } \mathrm{Si}- \\
\text { mülasyon tabanlı tabu arama yöntemi }\end{array}$ & Ameliyat tiplerini çizelgeleme & $\begin{array}{l}\text { Ameliyat iptallerini, ameliyatların tamam- } \\
\text { lanma sürelerini, hastaların bekleme sürele- } \\
\text { rini azaltmayı hedeflemişlerdir. }\end{array}$ \\
\hline 2015 & $\begin{array}{l}\text { Saadouli ve } \\
\text { di } \breve{g} \text {. }\end{array}$ & Tunus & $\begin{array}{l}\text { Sirt çantası modeli, karma tamsayılı } \\
\text { programlama algoritması ve ARENA } \\
\text { yazılımını kullanarak AOS }\end{array}$ & $\begin{array}{l}\text { Hasta çizelgeleme problemi ve mev- } \\
\text { cut strateji ile önerilen stratejinin per- } \\
\text { formansını karşılaştırmak }\end{array}$ & $\begin{array}{l}\text { Sırt çantası modeli: Eşzamanlı olarak fazla } \\
\text { mesai süresini ve ameliyat odalarının ye- } \\
\text { tersiz kullanımını en aza indirmeyi amaç- } \\
\text { lamışlardır. } \\
\text { Karma tamsayılı programlama: Her bir } \\
\text { ameliyatın maksimum tamamlanma süresini } \\
\text { ve odanın toplam bekleme süresini en aza } \\
\text { indirmeyi amaçlamışlardır. } \\
\text { AOS: Her bir ameliyat edilen hastanın atan- } \\
\text { dığı iyileşme odası yataklarını en aza indir- } \\
\text { meyi amaçlamışlardır. }\end{array}$ \\
\hline 2015 & $\begin{array}{l}\text { Astaraky \& } \\
\text { Patrick }\end{array}$ & Kanada & $\begin{array}{l}\text { Simülasyona dayalı dinamik prog- } \\
\text { ramlama }\end{array}$ & $\begin{array}{l}\text { Hasta talebi ile ameliyat tarihi arasın- } \\
\text { daki süreyi, ameliyathanede yaşana- } \\
\text { bilecek fazla mesai durumunu ve sis- } \\
\text { temde yaşanacak darboğaz nedeniyle } \\
\text { oluşabilecek hasta bekleme süreleri } \\
\end{array}$ & $\begin{array}{l}\text { Hem ameliyathanenin hem de iyileşme ya- } \\
\text { taklarının kullanım verimliğinin dikkate } \\
\text { alan bir ana cerrahi çizelgeleme yaratmış- } \\
\text { lardır. }\end{array}$ \\
\hline 2015 & $\begin{array}{l}\text { Duma \& } \\
\text { Aringhieri }\end{array}$ & & $\begin{array}{l}\text { AnyLogic } 6.9 \text { ve Java yazılımlarını } \\
\text { kullanarak melez simülasyon tekniği }\end{array}$ & $\begin{array}{l}\text { Ameliyatların iptallerine, gecikmelere } \\
\text { ve fazla mesailere neden olan hasta- } \\
\text { lar için gerçek zamanlı ameliyathane } \\
\text { çizelgeleme }\end{array}$ & $\begin{array}{l}\text { Bekleme listesini uzunluğuna ve bekleme } \\
\text { zamanına bağlı olarak en aza indirgemeyi } \\
\text { amaçlamışlardır. }\end{array}$ \\
\hline 2015 & $\begin{array}{l}\text { Landa ve } \\
\text { diğ. }\end{array}$ & $\begin{array}{l}\text { Genova, } \\
\text { İtalya }\end{array}$ & $\begin{array}{l}\text { Tamsayılı doğrusal rassal algoritma } \\
\text { ve Monte-Carlo simülasyonu ile } \\
\text { komşuluk arama tekniklerinin kar- } \\
\text { ması olan iki aşamalı bir iyileştirme } \\
\text { algoritması }\end{array}$ & Ameliyat çizelgeleme & $\begin{array}{l}\text { "İleri çizelgeleme" aşaması ile ameliyat ta- } \\
\text { rihlerini ve } \\
\text { "atama çizelgeleme" aşaması ile hasta akı- } \\
\text { şını bir sıra halinde belirlemişlerdir. }\end{array}$ \\
\hline
\end{tabular}




\begin{tabular}{|c|c|c|c|c|c|}
\hline 2017 & $\begin{array}{l}\text { Samudra ve } \\
\text { diğ. }\end{array}$ & $\begin{array}{l}\text { Leuven, } \\
\text { Belçika }\end{array}$ & $\begin{array}{l}\text { MATLAB ve Simulink yazılımlarını } \\
\text { kullanarak AOS }\end{array}$ & Hasta çizelgeleme & $\begin{array}{l}\text { Planlı olmayan hasta gelişlerinin çizelgelen- } \\
\text { mesi kararını da modele ekleyerek ameliyat } \\
\text { zamanından önce hasta çizelgeleme planını } \\
\text { yeniden oluşturmuşlardır ve oluşabilecek } \\
\text { sağlık risklerini azaltabilmek için hasta bek- } \\
\text { leme sürelerini azaltmayı hedeflemişlerdir. }\end{array}$ \\
\hline \multicolumn{6}{|c|}{ Operasyon Çizelgeleme } \\
\hline $\begin{array}{l}\text { Yayın } \\
\text { Yllı }\end{array}$ & Yazar & Ülke & Kullanılan Yöntemler & Ele Alınan Problem & Sonuçlar \\
\hline 2013 & $\begin{array}{l}\text { Banditori ve } \\
\text { diğ. }\end{array}$ & $\begin{array}{l}\text { Floransa, } \\
\text { İtalya }\end{array}$ & $\begin{array}{l}\text { Karma tamsayılı programlama opti- } \\
\text { mizasyonu ile birleştirilmiş AOS }\end{array}$ & $\begin{array}{l}\text { Ameliyathane odası, ameliyat sonrası } \\
\text { yatak gibi kaynakların kullanılabilir- } \\
\text { liğini göz önünde bulunduran ana cer- } \\
\text { rahi planlama }\end{array}$ & $\begin{array}{l}\text { Planlanan ameliyat sayısını en büyüklemek } \\
\text { için, gecikmeler ve yatak uyumsuzlukların- } \\
\text { dan kaynaklanan cezaları en aza indirmeyi } \\
\text { hedeflemişlerdir. }\end{array}$ \\
\hline 2017 & Xiang & $\begin{array}{l}\text { Teksas, } \\
\text { ABD }\end{array}$ & $\begin{array}{l}\text { MATLAB yazılımını kullanarak, Pa- } \\
\text { reto çözüm setleri ve Karınca Kolo- } \\
\text { nisi Optimizasyonu yaklaşımını içe- } \\
\text { ren meta-sezgisel bir yöntem }\end{array}$ & $\begin{array}{l}\text { Çok amaçlı bir ameliyathane çizel- } \\
\text { geleme }\end{array}$ & $\begin{array}{l}\text { 1. Amaç fonksiyonu: Ameliyatların tamam- } \\
\text { lanma zamanlarının en küçüklenmesi } \\
\text { 2. Amaç fonksiyonu: } \\
\text { Kaynakların çalışma zamanının en aza in- } \\
\text { dirilmesi } \\
\text { 3. Amaç fonksiyonu: } \\
\text { tüm kaynakların fazla mesai toplamını en } \\
\text { küçüklemek }\end{array}$ \\
\hline \multicolumn{6}{|c|}{ Kaynak Kısıtlı Çizelgeleme } \\
\hline $\begin{array}{l}\text { Yayın } \\
\text { Yllı } \\
\end{array}$ & Yazar & Ülke & Kullanılan Yöntemler & Ele Alınan Problem & Sonuçlar \\
\hline 2008 & $\begin{array}{l}\text { Van Oost- } \\
\text { rum ve diğ. }\end{array}$ & Hollanda & AOS & $\begin{array}{l}\text { Ameliyathanede gece gerçekleşen } \\
\text { ameliyatlar için personel çizelgeleme }\end{array}$ & $\begin{array}{l}\text { Cerrahların, ameliyathane ve anestezi hem- } \\
\text { şirelerinin ve diğer personeli dikkate alan } \\
\text { bir simülasyon modeli önermişlerdir. }\end{array}$ \\
\hline 2008 & $\begin{array}{l}\text { Arnaout \& } \\
\text { Sevag }\end{array}$ & Lübnan & $\begin{array}{l}\text { ARENA yazılımını kullanarak buluş- } \\
\text { sal algoritmalar }\end{array}$ & Ameliyathane çizelgeleme & $\begin{array}{l}\text { Ameliyathane odalarının kullanımını en bü- } \\
\text { yüklerken, ameliyatın tamamlanma zama- } \\
\text { nını en küçüklemeyi amaçlamışlardır. }\end{array}$ \\
\hline 2014 & $\begin{array}{l}\text { M'Hallah \& } \\
\text { Al-Roomi }\end{array}$ & & ARENA yazılımını kullanarak AOS & $\begin{array}{l}\text { Seçilmiş cerrahi vakalar için ameli- } \\
\text { yathane çizelgeleme }\end{array}$ & $\begin{array}{l}\text { Ameliyathanenin aşırı iş yükünü azalt- } \\
\text { mak için ameliyatın çevrimiçi seviyede ip- } \\
\text { tal edilmesi ve iş yükünün çevrimdışı se- } \\
\text { viyede sınırlandırılması olarak iki strateji } \\
\text { önermişlerdir. }\end{array}$ \\
\hline 2015 & $\begin{array}{l}\text { Molina-Pa- } \\
\text { riente ve } \\
\text { diğ. }\end{array}$ & İspanya & $\begin{array}{l}\text { Karma tamsayılı programlama opti- } \\
\text { mizasyonu ve AOS }\end{array}$ & Ameliyathane çizelgeleme & $\begin{array}{l}\text { Planlanan hasta sayısının maksimizasyonu, } \\
\text { gecikmenin en aza indirilmesi (Çizelgele- } \\
\text { nen tarih ile gerçekleşen tarih arasındaki } \\
\text { fark), Cerrahların ameliyatları arasında bek- } \\
\text { leme süresinin en aza indirilmesi amaçlan- } \\
\text { mıştır. }\end{array}$ \\
\hline
\end{tabular}

\section{SONUÇ}

Sonuç olarak yapılan ayrıntılı literatür çalışması ile mevcut süreçlerde yapılan iyileştirmeler sayesinde hastane işletmelerinin maliyetlerinde ciddi düşüşler sağlanırken hasta memnuniyetinin de artırılmasını mümkün kılan sağlık alanında gerçekleştirilen simülasyon çalışmalarının artarak devam edeceği açıktır. Bununla birlikte, sağlık sistemlerinde ve ameliyathane süreçlerinin iyileştirilmesi üzerine yapılan çalışmaların yurt dışında çok fazla olmasına karşın Türkiye'deki örneklerinin çok az olduğu saptanmıştır.

Ayrıca ameliyathane çizelgeme süreçlerinde daha çok k1sita yer veren modellere ihtiyaç olduğu, literatürde önerilen modellerin çoğunda sadece talep ve kapasite kısıtlarının dikkate alındığı gözlemlenmiştir. Özellikle iş gücü kapasite k1sıtları (anestezi uzmanları, hemşireler, vb.), cerrahların tercih kısıtları (ameliyat sırası), malzeme gereksinimi ile ilgili kısıtlar, ekipman değişim kısıtları, yoğun bakım ve servislerde yer alan yatak sayısı gibi kısıtlı kaynaklar modele dahil edilmelidir. Bununla birlikte belirsiz ameliyat ve iyileşme sürelerine yer veren stokastik modellerin geliştirilmesine ihtiyaç vardır. Yapılan çalışmaların çoğunda bu sürelerin kesin olarak bilindiği varsayılmıştır. Literatüre bakıldığında çok amaçlı modellerin sayısının da oldukça az olduğu saptanmıştır. Ayrıca çevrimiçi çizelgeleme konusunda çok az 
çalışma olduğu çalışmaların çoğunun çevrimdışı yaklaşıma sahip olduğu gözlemlenmiştir.

Literatürde tespit edilen bu boşlukları gelecek çalışmalarda doldurulabilmesi adına bu derleme çalışmasında son yıllarda gerçekleştirilen simülasyon çalışmaları sınıfland1rılmış ve özetlenmiştir. Çalışmanın, bu alanda çalışan akademisyen ve profesyonellerin gelecek araştırmalarına 1 şık tutarak ilgili literatüre önemli katkısı olacağı düşünülmektedir. Ayrıca, sağlık alanındaki politika yapıcılar ve yöneticiler, sağlık sektörüne yönelik stratejik kararların alınmasında mevcut süreçleri iyileştirmek adına çalışma kapsamında bahsedilen yöntem ve analizleri kullanabilirler.

\section{Teşekkür}

Bu çalışma, İstanbul Medipol Üniversitesi 2017/16 no.lu Bilimsel Araştırma Projesi (BAP) kapsamında desteklenmiş̧ir.

\section{Kaynaklar}

[1] Schroedl, C. J., Corbridge, T. C., Cohen, E. R., Fakhran, S. S., Schimmel, D., McGaghie, W. C., ve Wayne, D. B. (2012). Use of Simulation-Based Education to Improve Resident Learning And Patient Care in The Medical Intensive Care Unit: A Randomized Trial. J Crit Care, 27(2), 217-213.

[2] Jansson, M., Kääriäinen, M. ve Kyngäs, H. (2013). Effectiveness of Simulation-Based Education in Critical Care Nurses' Continuing Education: A Systematic Review. Clinical Simulation in Nursing, 9(9), 355-60.

[3] Ballangrud, R., Hall-Lord, M. L., Persenius, M., ve Hedelin, B. (2014). Intensive Care Nurses' Perceptions of Simulation-Based Team Training for Building Patient Safety in Intensive Care: a Descriptive Qualitative Study. Intensive Crit Care Nurs, 30(4), 179-187.

[4] Wenk, M., ve Popping, D. M. (2015). Simulation for Anesthesia in Obstetrics. Best Pract Res Clin Anaesthesiol, 29(1), 81-86.

[5] Warren, J. N., Luctkar-Flude, M., Godfrey, C., \& Lukewich, J. (2016). A Systematic Review of the Effectiveness of Simulation-Based Education on Satisfaction and Learning Outcomes in Nurse Practitioner Programs. Nurse Educ Today, 46, 99-108.

[6] Mirza, S., \& Athreya, S. (2017). Review of Simulation Training in Interventional Radiology. Acad Radiol, 25(4), 529539.

[7] Camp, S., \& Legge, T. (2018). Simulation as a Tool for Clinical Remediation: An Integrative Review. Clinical Simulation in Nursing, 16, 48-61.

[8] Reed, S., Remenyte-Prescott, R., ve Rees, B. (2017). Effect of Venepuncture Process Design on Efficiency and Failure Rates: A Simulation Model Study for Secondary Care. Int $J$ Nurs Stud, 68, 73-82.
[9] Fabian, M.P., Stout, N.K., Adamkiewicz, G., Geggel, A., Ren, C., Sandel, M., Levy, J.I. (2012). The Effects of Indoor Environmental Exposure Pediatric Asthma: A Discrete Event Simulation Model. Environmental Health, 11(1), 66.

[10] Chemweno, P., Thijs, V., Pintelon, L., \& Van Horenbeek, A. (2014). Discrete Event Simulation Case Study: Diagnostic Path for Stroke Patients in A Stroke Unit. Simulation Modelling Practice and Theory, 48, 45-57.

[11] Ariöz, U., ve Günel, B. (2016). Evaluation of Hearing Loss Simulation Using A Speech Intelligibility Index. Turkish Journal of Electrical Engineering \& Computer Sciences, 24, 4193-4207.

[12] Pan, F., Reifsnider, O., Zheng, Y., Proskorovsky, I., Li, T., He, J., ve Sorensen, S. V. (2017). Modeling Clinical Outcomes in Prostate Cancer: Application and Validation of the Discrete Event Simulation (DES) Approach. Value in Health. 21(4), 416-422.

[13] Nikakhtar, A., ve Hsiang, S. M. (2014). Incorporating The Dynamics of Epidemics in Simulation Models of Healthcare Systems. Simulation Modelling Practice and Theory, 43, 6778.

[14] Viana, J., Brailsford, S. C., Harindra, V., ve Harper, P. R. (2014). Combining Discrete-Event Simulation and System Dynamics in A Healthcare Setting: A Composite Model for Chlamydia Infection. EJOR, 237(1), 196-206.

[15] Orbann, C., Sattenspiel, L., Miller, E., ve Dimka, J. (2017). Defining Epidemics in Computer Simulation Models: How Do Definitions Influence Conclusions?. Epidemics, 19, 2432.

[16] Sadatsafavi, H., Niknejad, B., Zadeh, R., ve Sadatsafavi, M. (2016). Do Cost Savings From Reductions in Nosocomial Infections Justify Additional Costs of Single-Bed Rooms in Intensive Care Units? A simulation Case Study. J Crit Care, 31(1), 194-200.

[17] Granja, C., Almada-Lobo, B., Janela, F., Seabra, J., ve Mendes, A. (2014). An Optimization Based on Simulation Approach to The Patient Admission Scheduling Problem Using A Linear Programing Algorithm. J Biomed Inform, 52, 427-437.

[18] Ben-Tovim, D., Filar, J., Hakendorf, P., Qin, S., Thompson, C., ve Ward, D. (2016). Hospital Event Simulation Model: Arrivals to Discharge-Design, Development and Application. Simulation Modelling Practice and Theory, 68, 80-94.

[19] Ahmadi-Javid, A., Jalali, Z., ve Klassen, K. J. (2017). Outpatient Appointment Systems in Healthcare: A Review of Optimization Studies. EJOR, 258(1), 3-34.

[20] Jun, J. B., Jacobson, S. H., ve Swisher, J. R. (1999). Application of Discrete-Event Simulation in Health Care Clinics: A Survey. The Journal of the Operational Research Society, 50(2), 109-123.

[21] Fone, D., Hollinghurst, S., Temple, M., Round, A., Lester, N., Weightman, A., Roberts, K., Coyle, E., Bevan, G., Palmer, S. (2003). Systematic Review of The Use and Value of Computer Simulation Modelling in Population Health and Health 
Care Delivery. Journal of Public Health Medicine, 25(4), 325-335.

[22] Günal, M. M., ve Pidd, M. (2017). Discrete Event Simulation for Performance Modelling in Health Care: A Review of The Literature. Journal of Simulation, 4(1), 42-51.

[23] Faezipour, M., ve Ferreira, S. (2013). A System Dynamics Perspective of Patient Satisfaction in Healthcare. Procedia Computer Science, 16, 148-156.

[24] Kumar, D., ve Kumar, D. (2014). Modelling Rural Healthcare Supply Chain in India using System Dynamics. Procedia Engineering, 97, 2204-2212.

[25] Gonul Kochan, C., Nowicki, D. R., Sauser, B., ve Randall, W. S. (2018). Impact of Cloud-Based Information Sharing on Hospital Supply Chain Performance: A System Dynamics Framework. International Journal of Production Economics, 195, 168-185.

[26] Cabrera, E., Taboada, M., Iglesias, M. L., Epelde, F., ve Luque, E. (2011). Optimization of Healthcare Emergency Departments by Agent-Based Simulation. Procedia Computer Science, 4, 1880-1889.

[27] Silverman, B. G., Hanrahan, N., Bharathy, G., Gordon, K., ve Johnson, D. (2015). A Systems Approach to Healthcare: Agent-Based Modeling, Community Mental Health, and Population Well-Being. Artif Intell Med, 63(2), 61-71.

[28] Liu, Z., Rexachs, D., Epelde, F., ve Luque, E. (2017). An Agent-Based Model For Quantitatively Analyzing and Predicting The Complex Behavior of Emergency Departments. Journal of Computational Science, 21, 11-23.

[29] Aringhieri, R., Landa, P., Soriano, P., Tànfani, E., ve Testi, A. (2015). A Two Level Metaheuristic for The Operating Room Scheduling and Assignment Problem. Computers \& Operations Research, 54, 21-34.

[30] Molina-Pariente, J. M., Hans, E. W., Framinan, J. M., ve Gomez-Cia, T. (2015). New Heuristics for Planning Operating Rooms. Computers \& Industrial Engineering, 90, 429-443.

[31] Xiang, W., Yin, J., ve Lim, G. (2015). An Ant Colony Optimization Approach for Solving An Operating Room Surgery Scheduling Problem. Computers \& Industrial Engineering, 85, 335-345.

[32] Hoot, N. R., LeBlanc, L. J., Jones, I., Levin, S. R., Zhou, C., Gadd, C. S., ve Aronsky, D. (2008). Forecasting Emergency Department Crowding: A Discrete Event Simulation. Ann Emerg Med, 52(2), 116-125.

[33] Khurma, N., Bacioiu, G. M., ve Pasek, Z. J. (2008). Simulation-Based Verification of Lean Improvement for Emergency Room Process. Proceedings of the 40th Conference on Winter Simulation Conference, 1490-1499.

[34] Zeng, Z., Ma, X., Hu, Y., Li, J., ve Bryant, D. (2012). A Simulation Study to Improve Quality of Care in The Emergency Department of A Community Hospital. J Emerg Nurs, 38(4), 322-328.

[35] Al-Refaie, A., Fouad, R. H., Li, M.-H., ve Shurrab, M. (2014). Applying Simulation and DEA to Improve Performance of
Emergency Department in A Jordanian Hospital. Simulation Modelling Practice and Theory, 41, 59-72.

[36] Best, A. M., Dixon, C. A., Kelton, W. D., Lindsell, C. J., ve Ward, M. J. (2014). Using Discrete Event Computer Simulation to Improve Patient Flow in A Ghanaian Acute Care Hospital. Ann J Emerg Med, 32(8), 917-922.

[37] Radhakrishnan, S., Duvvuru, A., ve Kamarthi, S. V. (2014). Investigating Discrete Event Simulation Method to Assess the Effectiveness of Wearable Health Monitoring Devices. Procedia Economics and Finance, 11, 838-856.

[38] Lin, C. H., Kao, C. Y., \& Huang, C. Y. (2015). Managing Emergency Department Overcrowding via Ambulance Diversion: A Discrete Event Simulation Model. J Formos Med Assoc, 114(1), 64-71.

[39] Azadeh, A., Baghersad, M., Farahani, M.H., ve Zarrin, M. (2015). Semi-Online Patient Scheduling in Pathology Laboratories. Artificial Intelligence in Medicine, 64(3), 217-226.

[40] Ünlüyurt, T., ve Tunçer, Y. (2016). Estimating The Performance of Emergency Medical Service Location Models via Discrete Event Simulation. Computers \& Industrial Engineering, 102, 467-475.

[41] Coelli, F. C., Ferreira, R. B., Almeida, R. M., ve Pereira, W. C. (2007). Computer Simulation and Discrete-Event Models in The Analysis of A Mammography Clinic Patient Flow. Comput Methods Programs Biomed, 87(3), 201-207.

[42] Kapamara, T., Sheibani, K., Petrovic, D., Haas, O. C. L., ve Reeves, C. (2014). A Simulation of A Radiotherapy Rreatment System: A Case Study of A Local Cancer Center. in Proceedings of ORP3, EURO: Cadiz, Spain, 29-35.

[43] J. Klassen, K., ve Yoogalingam, R. (2009). Improving Performance in Outpatieint Appointment Services with a Simulation Optimization Approach. Production and Operations Management, 18(4), 447-458.

[44] Villamizar, J. R., Coelli, F. C., Pereira, W. C., ve Almeida, R. M. (2011). Discrete-Event Computer Simulation Methods in The Optimisation of A Physiotherapy Clinic. Physiotherapy, 97(1), 71-77.

[45] Rohleder, T. R., Lewkonia, P., Bischak, D. P., Duffy, P., ve Hendijani, R. (2011). Using Simulation Modeling to Improve Patient Flow at An Outpatient Orthopedic Clinic. Health Care Manag Sci, 14(2), 135-145.

[46] Masselink, I. H. J., van der Mijden, T. L. C., Litvak, N., ve Vanberkel, P. T. (2012). Preparation of Chemotherapy Drugs: Planning Policy For Reduced Waiting Times. Omega, 40(2), 181-187.

[47] Baril, C., Gascon, V., ve Cartier, S. (2014). Design and Analysis of An Outpatient Orthopaedic Clinic Performance with Discrete Event Simulation and Design of Experiments. Computers \& Industrial Engineering, 78, 285-298.

[48] Peng, Y., Qu, X., ve Shi, J. (2014). A Hybrid Simulation and Genetic Algorithm Approach to Determine The Optimal Scheduling Templates for Open Access Clinics Admitting 
Walk-In Patients. Computers \& Industrial Engineering, 72, 282-296.

[49] Baril, C., Gascon, V., Miller, J., ve Côté, N. (2016). Use of A Discrete-Event Simulation in A Kaizen Event: A Case Study in Healthcare. EJOR, 249(1), 327-339.

[50] Babashov, V., Aivas, I., Begen, M. A., Cao, J. Q., Rodrigues, G., D’Souza, D., Lock, M., Zaric, G. S. (2017). Reducing Patient Waiting Times for Radiation Therapy and Improving the Treatment Planning Process: a Discrete-event Simulation Model (Radiation Treatment Planning). Clin Oncol ( $R$ Coll Radiol), 29(6), 385-391.

[51] Kim, B., Elstein, Y., Shiner, B., Konrad, R., Pomerantz, A. S., ve Watts, B. V. (2013). Use of Discrete Event Simulation to Improve A Mental Health Clinic. Gen Hosp Psychiatry, 35(6), 668-670.

[52] Chemweno, P., Thijs, V., Pintelon, L., ve Van Horenbeek, A. (2014). Discrete Event Simulation Case Study: Diagnostic Path for Stroke Patients in A Stroke Unit. Simulation Modelling Practice and Theory, 48, 45-57.

[53] Devapriya, P., Stromblad, C. T., Bailey, M. D., Frazier, S., Bulger, J., Kemberling, S. T., ve Wood, K. E. (2015). StratBAM: A Discrete-Event Simulation Model to Support Strategic Hospital Bed Capacity Decisions. J Med Syst, 39(10), 130.

[54] Reynolds, M., Vasilakis, C., McLeod, M., Barber, N., Mounsey, A., Newton, S., Jacklin, A., Franklin, B. D. (2011). Using Discrete Event Simulation to Design A More Efficient Hospital Pharmacy for Outpatients. Health Care Manag Sci, 14(3), 223-236.

[55] Dan, Z., Xiaoli, H., Weiru, D., Li, W., ve Yue, H. (2016). Outpatient Pharmacy Optimization Using System Simulation. Procedia Computer Science, 91, 27-36.

[56] Rodrigues, F., Zaric, G. S., ve Stanford, D. A. (2017). Discrete Event Simulation Model for Planning Level 2 "StepDown” Bed Needs Using NEMS. Operations Research for Health Care. 17, 42-54.

[57] Lamiri M., Dreo, J., Xie, X. (2007). Operating Room Planning with Random Surgery Times. In: Proceedings of the 3rd Annual IEEE Conference on Automation Science and Engineering, Sept 22-25. Scottsdale, AZ, USA.

[58] Lamiri, M., Grimaud, F. ve Xie, X. (2009). Optimization Methods for A Stochastic Surgery Planning Problem. International Journal of Production Economics, 120(2), 400-410.

[59] Persson, M. J ve Persson, J. A. (2010). Analysing Management Policies for Operating Room Planning Using Simulation. Health Care Manag Sci, 13(2), 182-191.

[60] Niu, Q., Peng, Q., El Mekkawy, T., Tan, Y. Y., Bruant, H. ve Bernaerdt, L. (2011). Performance Analysis of The Operating Room Using Simulation. Proceedings of the Canadian Engineering Education Association.

[61] Chow, V. S., Puterman, M. L., Salehirad, N., Huang, W. ve Atkins, D. (2011). Reducing Surgical Ward Congestion Through Improved Surgical Scheduling and Uncapacitated
Simulation. Production and Operations Management, 20(3), 418-430.

[62] Gul, S., Denton, B. T., Fowler, J. W. ve Huschka. T. (2011). Bi-Criteria Scheduling of Surgical Services for An Outpatient Procedure Center. Production and Operations Management, 20(3), 406-417.

[63] Batun, S., Denton, B. T., Huschka, T. R. ve Schaefer, A. J. (2011). Operating Room Pooling and Parallel Surgery Processing Under Uncertainty. INFORMS Journal on Computing, 23(2), 220-237.

[64] Saremi, A., Jula, P., El Mekkawy, T. ve Wang, G. G. (2013). Appointment Scheduling of Outpatient Surgical Services in A Multistage Operating Room Department. International Journal of Production Economics, 141(2), 646-658.

[65] Aringhieri, R., Landa, P., Soriano, P., Tànfani, E. ve Testi, A. (2015). A Two Level Metaheuristic for The Operating Room Scheduling and Assignment Problem. Computers \& Operations Research, 54, 21-34.

[66] Saadouli, H., Jerbi, B., Dammak, A., Masmoudi, L. ve Bouaziz, A. (2015). A Stochastic Optimization and Simulation Approach for Scheduling Operating Rooms and Recovery Beds in An Orthopedic Surgery Department. Computers \& Industrial Engineering, 80, 72-79.

[67] Astaraky, D. ve Patrick, J. (2015). A Simulation Based Approximate Dynamic Programming Approach to Multi-Class, Multi-Resource Surgical Scheduling. EJOR, 245(1), 309319.

[68] Duma, D. ve Aringhieri, R. (2015). An Online Optimization Approach for The Real Time Management of Operating Rooms. Operations Research for Health Care, 7, 40-51.

[69] Landa, P., Aringhieri, R., Soriano, P., Tànfani, E. ve Testi, A. (2016). A Hybrid Optimization Algorithm for Surgeries Scheduling. Operations Research for Health Care, 8, 103-114.

[70] Yahia, Z., Eltawil, A. B. ve Harraz, N. A. (2016). The Operating Room Case-Mix Problem Under Uncertainty and Nurses Capacity Constraints. Health Care Manag Sci , 19 (4), 383394.

[71] Samudra, M., Demeulemeester, E., Cardoen, B., Vansteenkiste, N. ve Rademakers, F. E. (2017). Due Time Driven Surgery Scheduling. Health Care Manag Sci, 20 (3), 326-352.

[72] Banditori, C., Cappanera, P. ve Visintin, F. (2013). A Combined Optimization \{Simulation Approach to The Master Surgical Scheduling Problem. IMA Journal of Management Mathematics, 24(2), 155-187.

[73] Xiang, W. (2017). A Multi-Objective Aco for Operating Room Scheduling Optimization. Natural Computing, 16(4), 607-617.

[74] van Oostrum, J. M., Van Houdenhoven, M., Vrielink, M. MJ., Klein, J., Hans, E. W., Klimek, M., Wullink, G., Steyerberg, E. W. ve Kazemier, G. (2008). A Simulation Model for Determining The Optimal Size of Emergency Teams on Call in The Operating Room at Night. Anesthesia \& Analgesia, 107(5), 1655-1662. 
[75] Arnaout, J. ve Kulbashian, S. (2008). Maximizing The Utilization of Operating Rooms with Stochastic Times Using Simulation. In Proceedings of The 40th Conference on Winter Simulation, Winter Simulation Conference. pages 1617-1623.

[76] Beliën, J., Demeulemeester, E. ve Cardoen, B. (2009). A Decision Support System for Cyclic Master Surgery Scheduling with Multiple Objectives. Journal of Scheduling, 12(2), 147.
[77] MHallah, R. ve Al-Roomi, A. (2014). The Planning and Scheduling of Operating Rooms: A Simulation Approach. Computers \& Industrial Engineering, 78, 235-248.

[78] Molina-Pariente, J. M., Hans, E. W., \& Framinan, J. M. (2018). A Stochastic Approach for Solving The Operating Room Scheduling Problem. Flexible Services and Manufacturing Journal, 30(1-2), 224-251. 